OPEN ACCESS

Edited by:

Felix Broecker,

Idorsia Pharmaceuticals Ltd,

Switzerland

Reviewed by:

Yuanqiang Zou,

Beijing Genomics Institute (BGI), China Jane Adair Mullaney,

AgResearch Ltd, New Zealand

${ }^{*}$ Correspondence:

Yanjiao Zhou

yazhou@uchc.edu

Specialty section:

This article was submitted to Microbiome in Health and Disease,

a section of the journal

Frontiers in Cellular and

Infection Microbiology

Received: 18 May 2021

Accepted: 24 August 2021

Published: 21 September 2021

Citation:

Bokoliya SC, Dorsett Y, Panier H and Zhou Y (2021) Procedures for

Fecal Microbiota Transplantation

in Murine Microbiome Studies.

Front. Cell. Infect. Microbiol. 11:711055.

doi: 10.3389/fcimb.2021.711055

\section{Procedures for Fecal Microbiota Transplantation in Murine Microbiome Studies}

\author{
Suresh C. Bokoliya, Yair Dorsett, Hunter Panier and Yanjiao Zhou* \\ Department of Medicine, University of Connecticut (UConn) Health, Farmington, CT, United States
}

Fecal microbiota transplantation (FMT) has been widely recognized as an approach to determine the microbiome's causal role in gut dysbiosis-related disease models and as a novel disease-modifying therapy. Despite potential beneficial FMT results in various disease models, there is a variation and complexity in procedural agreement among research groups for performing FMT. The viability of the microbiome in feces and its successful transfer depends on various aspects of donors, recipients, and lab settings. This review focuses on the technical practices of FMT in animal studies. We first document crucial factors required for collecting, handling, and processing donor fecal microbiota for FMT. Then, we detail the description of gut microbiota depletion methods, FMT dosages, and routes of FMT administrations in recipients. In the end, we describe assessments of success rates of FMT with sustainability. It is critical to work under the anaerobic condition to preserve as much of the viability of bacteria. Utilization of germ- free mice or depletion of recipient gut microbiota by antibiotics or polyethylene glycol are two common recipient preparation approaches to achieve better engraftment. Oral-gastric gavage preferred by most researchers for fast and effective administration of FMT in mice. Overall, this review highlights various methods that may lead to developing the standard and reproducible protocol for FMT.

Keywords: fecal microbiota transplantation, mice, microbiome, engraftment, procedure

\section{INTRODUCTION}

The human microbiota harbors an extensive reservoir of genetic information encoded within $\sim 10$ to 100 trillion microbial cells present throughout the human body. Most of this genetic information is present within the human gastrointestinal tract and is commonly referred to as our "second genome". The 1100 gut microbial species are central to the proper development and function of numerous physiological processes such as sustaining homeostasis in gut barrier integrity (Shi et al., 2017), nutrition metabolism (Nicholson et al., 2012), host immunity (Olszak et al., 2012) and the regulation of neuropsychological behaviors (Diaz Heijtz et al., 2011).

Microbiome research has made tremendous strides in the past decade. After the initial characterization of the microbiome in the healthy population from the Human Microbiome Project (Human Microbiome Project, 2012a; Human Microbiome Project, 2012b), accumulating data from animal and human studies have advocated that gut microbiome dysbiosis (alteration) is 
associated with onset, development, and progression of gastrointestinal (Chang and Lin, 2016), metabolic (Dabke et al., 2019), autoimmune (Xu et al., 2019), neurologic (Felice and O'Mahony, 2017), and psychiatric diseases (Cenit et al., 2017). Research is rapidly moving from association to causation by experimentally manipulating the gut microbiome to precisely understand the contribution and underlying mechanisms of microbiome in disease. Fecal microbiota transplantation (FMT) is one of the most commonly used approaches for investigating the causal connection between the gut microbiome and diseases in animal models. FMT has shown that the transplanted microbiome can influence physiological functions and alleviate a wide range of diseases that include Clostridium Difficile infection (CDI), inflammatory bowel diseases (IBD), irritable bowel syndrome (IBS), obesity, diabetes, aging, cancer, autism, multiple sclerosis (Evrensel and Ceylan, 2016), Parkinson's disease (Sun et al., 2018), anorexia nervosa, food allergies and neurological disorders (Bajaj et al., 2017; Kang et al., 2017; Wang et al., 2018a) in animal models. These findings have spearheaded the advancement of targeted microbiome therapeutic using FMT for the treatment of human diseases.

Although FMTs are widely used for studying causality in disease models, standard protocols for relevant FMT procedures do not exist for even basic procedures such as donor stool preparation (selection, storage and processing), delivery mode, dosage, duration of administration and recipient preparation. Such experimental variation complicates the interpretation of results across studies. In this review, we provide a detailed summary of the techniques currently utilized for FMTs in animal studies including FMT from mouse to mouse and human to mouse) (Figure 1) and call for standardizing protocols to increase rigor and reproducibility of critical approach for microbiome research and therapeutics.

\section{EVIDENCE OF FMT IN MODIFYING DISEASE DEVELOPMENT}

Several animal studies have demonstrated the benefits of FMT in preventing and treating diseases. Lawley's research group reported that FMT from a healthy donor mouse into recipient mouse with CDI led to resolution of illness and infection (Lawley et al., 2012). A study by Palma et al. reported altered gastrointestinal function, activation of innate immunity, and anxiety-like behavior in germfree (GF) mice treated with feces matter of diarrheal IBS patients (De Palma et al., 2017). FMT improves colitis symptoms in the mouse model by upregulating aryl hydrocarbon receptors (Wei et al., 2018). Ferrere and his colleagues reported the prevention of alcoholic liver disease in mice when treated with the fecal transplant of alcohol-fed donor mice resistant to alcoholic liver disease (Ferrere et al., 2017). A recent study reported decrement or limitation in the accumulation of p-cresyl sulfate and uremic toxins after FMT from healthy mice into mice with chronic kidney disease (Barba et al., 2020). FMT also reverses the course of lethal sepsis by improving pathogen clearance through the restoration of host immunity in an interferon regulatory factor 3dependent method (Kim et al., 2020). FMT of resveratrol-fed mice enhanced glucose homeostasis and cardiovascular symptoms and reduced the high blood pressure in a mouse model of hypertension (Kim et al., 2018b). FMT also alleviates high-fat diet-induced steatohepatitis in mice via restoring the beneficial regulation of gut microbiota (Zhou et al., 2017). FMT might lessen obesity and digestion in both humans and mice (Ridaura et al., 2013). Bárcena's research group found that FMT from wild-type mice improved health span and life expectancy in progeroid mice. The re-establishment of secondary bile acids is a potential mechanism for restoring a healthy microbiome (Barcena et al., 2019). A number of reports support a protecting role of specific FMT

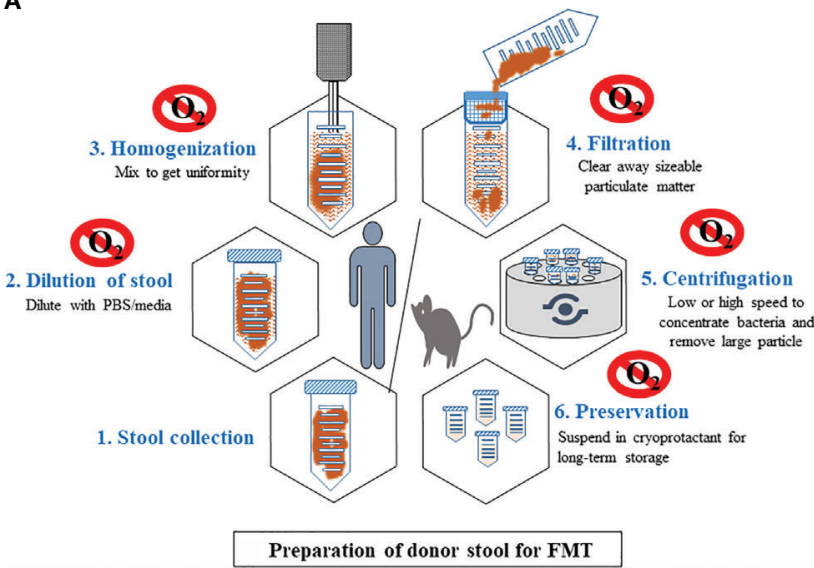

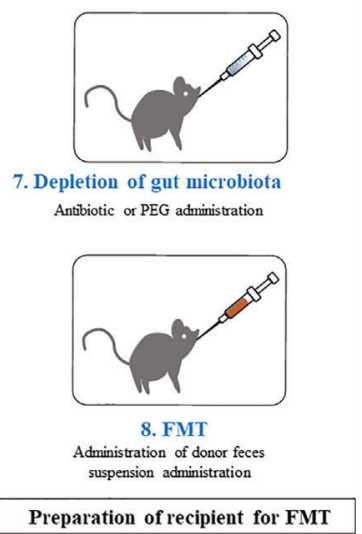

FIGURE 1 | General procedures for FMT in murine. Step-wised procedures of FMT from human or mice donors to mice recipients. This includes preparation of donor stool (A) and preparation of recipients (B). Preparation of donor stool is recommended in anaerobic environment. Raw stools will be diluted, homogenized, filtered, followed by centrifuge to remove large particles. Processed stool can be stored in long term in -800C. Recipient mice will treated with antibiotics or PEG to deplete the majority of the gut microbiota, providing an ecological niche for colonization of transplanted stool microbiota. 
against development and progression of melanoma (Le Bastard et al., 2018; Wang et al., 2019) possibly enhancing anti-tumor immune responses mediated by increased dendritic cells activity, and improved priming of CD8 $\mathrm{T}$ cells in and around the tumor microenvironment.

FMT also shows encouraging results in neuropsychological diseases. FMT from resilient rats significantly reduced the pain and depression in antibiotic administered pseudo-germ-free mice (Yang et al., 2019). A recent report advocated FMT of youth gut microbiome in aged mice to reverse the weak stroke recovery (Lee et al., 2020). Remarkably, FMT inhibited the TLR4/ TBK1/NF- $\mathrm{KB} / \mathrm{TNF}-\mathrm{a}$ signaling pathway, reduced gut microbial dysbiosis, decreased the activation of brain microglia and astrocytes, and alleviated physical impairment in Parkinson's disease mice (Sun et al., 2018; Sun et al., 2019). Multiple sclerosis derived gut microbiome contains factors that precipitate numerous sclerosis in a humanized mouse model (Berer et al., 2017). FMT also contains unidentified microbes can be potentially pathogenic (Elinav et al., 2011; Food and Drug Administration, 2020) that exacerbate illness or even be fatal for recipients. Further, FMT might induce obesity as metabolic syndrome in recipients as a long-term effect (Ridaura et al., 2013). FMT can also be the risk of infection or overt immune reaction in immunocompromised recipients (Carlson, 2020). These reports suggest that FMT also has some limitations that need to be evaluated for its continued development.

\section{DONOR STOOL PREPARATION FOR FMT}

\subsection{Timing of Stool Collection}

Collection timing of stool is imperative given reports signifying the circadian rhythms of the abundance of gut microbiota. Diurnal rhythmicity reported in $20-83 \%$ of mice gut microbiota (Zarrinpar et al., 2014). Around $20 \%$ of human gut microbiota displayed diurnal fluctuations in average abundance (Thaiss et al., 2014). Clostridiales, Lactobacillales, and Bacteroidales, which comprise $60 \%$ of total gut microbiota, displayed acrophase and bathyphase in abundance throughout the 24-hour cycle. Noticeably, the bacterial rhythmicity was independent of cage or housing conditions (Thaiss et al., 2014).

Liang and his research group found that bacterial load was highest during night time (11:00 PM), and the lowest load was reported early morning (7:00 AM). Bacterial load steadily increased from the early light phase and decreased toward the late-night dark stage (midnight). The average higher richness (60-66\%) of Bacteroidetes was noted at 11:00 PM and 11:00 AM and lower at other time points. The average higher richness (45\%) of Firmicutes was noted at 3:00 AM and 7:00 AM, and the lowest richness (29\%) was recorded at 11:00 PM. They also reported male mice had higher bacterial load than females, though females had higher bacterial rhythms (Liang et al., 2015). Some reports endorsed to collect mice fecal samples in the early morning between 7:00 AM to 11:00 AM (Ericsson et al., 2018) or afternoon between 3:00 PM to 5:00 PM to reduce potential circadian rhythm effects (Wang et al., 2018b). Due to mice nocturnal feeding actions, it will take less time to excrete the mice and collect the feces in the morning. For human donors, individuals delivered fresh stool one month after health screening (Bakken et al., 2011), however no specific rationale for stool collection timing was provided.

\subsection{Frozen-Thaw Stool vs. Fresh Stool}

Ericsson and his colleagues conducted an FMT study in mice with frozen and thawed stool in contrast with fresh stool to ensure microbes' viability after freezing. They stated that frozen feces and fresh cecal contents both performed comparably to fresh feces as the model source for FMT (Ericsson et al., 2017). Using frozen stool permit researchers to freeze and bank multiple samples for later use. However, the number of freezeand-thaw cycles has been described to influence microbial populations (Sergeant et al., 2012). It will be a standard lab practice to make aliquots of feces to prevent multiple freezes and thaw cycles (Thomas et al., 2015).

\subsection{Storage Condition of Stool}

Fecal samples kept at room temperature for up to twenty-four hours hold a microbiota comparable in composition to a fresh sample. Storage of feces at room temperature over 24 hours increases the abundance of Actinobacteria and decreases the abundance of Firmicutes (Choo et al., 2015). Feces sample cooled at $4^{\circ} \mathrm{C}$ did not vary significantly in the microbial community of the control feces samples stored at $-80^{\circ} \mathrm{C}$ for over twenty-four hours period (Tedjo et al., 2015). However, metabolic disease feces or IBS fecal samples are less stable throughout storage at room temperature (Roka et al., 2007; Tana et al., 2010). It is tempting to speculate that higher levels of proteases and acids may result in the rapid degradation of fecal DNA. Short-term storage of fecal material at $-20^{\circ} \mathrm{C}$ for one month exhibited similar enteric colonization ability frozen at $-80^{\circ} \mathrm{C}$ (Lauber et al., 2010). Long-span storage of transplanted fecal material at $-20^{\circ} \mathrm{C}$ for more than one month can result in uncertainty of the clinical outcome following FMT (Takahashi et al., 2019). During long-term storage at $-80^{\circ} \mathrm{C}$, fecal materials kept at up to six months retain a microbiota comparable in composition to a fresh sample (Carroll et al., 2012). There were reports showing that feces can maintain a steady microbial population for up to 2 years when stored at $-80^{\circ} \mathrm{C}$ (Shaw et al., 2016). Freezing of feces at $-20^{\circ} \mathrm{C}$ for around two months has been shown to increase the ratio of Firmicutes to Bacteroidetes (Bahl et al., 2012). Collectively, storing of stool samples streamlines the practical aspects of FMT with effectiveness or safety.

\subsection{Preservation of Stool}

Conservation of fecal transplants is essential to give rapid access to fecal material whose safety has been tested upstream in an allogenic context. Cryoprotection before freezing is a crucial step to preserve bacterial cell viability and integrity (Fadda, 2020). The currently recommended protocol advocates $10 \%$ glycerol for the conservation of frozen fecal samples (Cammarota et al., 2014). Glycerol is selected due to its low toxicity to bacterial cells intended for FMT (Hamilton et al., 2012). Storage of stool samples in normal saline causes a decline in all cultured 
microbiota compared to $10 \%$ glycerol solution except coliforms and Lactobacilli. A $10 \%$ glycerol is not appropriate for downstream lyophilization as it leads to a dry and sticky product. Cryoprotectants such as maltodextrin and trehalose can be good alternatives of glycerol+ dimethyl sulfoxide as they increase medium viscosity and limit ice crystallization and osmotic disparity during freezing. Cocktail recipes in the ratios of 3:1 maltodextrin and 1:3 trehalose in $\mathrm{NaCl}$ retained $>60 \%$ microbial viability in stored stool over a three-month period, a proportion which is little less to freshly prepared stool (Béal and Fonseca, 2015; Burz et al., 2019). It advised to include feces preservation method to prevent drastic change in viability when stored.

\subsection{Stool Processing (Anaerobic vs. Aerobic)}

The human gut consists mostly of anaerobic bacteria and sensitive to oxygen exposure. Anaerobic bacteria outnumber aerobic bacteria by a factor of 1000:1 (Finegold, 1995). Improper handling of the stool may lose the variability of many anaerobic bacteria, thus affects the effect of FMT. Approximately $61.69 \%$ of cells were alive when samples were exposed to oxygen $<2 \mathrm{~min}$, and cell viability decreased to $55.52 \%$ after exposure to oxygen for 90 minutes (Bellali et al., 2019). Under exposure to oxygen for $<2$ minutes viability was reduced to $49 \%$ (Ben-Amor et al., 2005). Another report stated anaerobic microbes viability $\sim 50 \%$ when the human stool was exposed to oxygen for $4-5$ minutes, falling to $0.1 \%$ post 40 minutes, and no cell was stayed alive after 2 hours (Brusa et al., 1989). Papanicolas and his colleagues found around $50 \%$ bacterial viability under stringent anaerobic conditions (Papanicolas et al., 2019). Homogenization in ambient air or freeze-thaw sequence reduced microbial viability to $19 \%$ and $23 \%$, correspondingly. Processing of fecal samples in ambient air can be a cause of multifold declines in the abundance of Faecalibacterium prausnitzii (12 fold decline), Subdoligranulum variable (8 fold decline), Eubacterium hallii (5 fold decline), and $\sim 3$ fold decline in Ruminococcus, Roseburia, lachnospira, and Dorea abundance (Papanicolas et al., 2019). Processing of fecal slurries in ambient air significantly reduced the production of short-chain fatty acids such as butyrate and acetate and the capacity for biosynthesis of important anti-inflammatory metabolites (Papanicolas et al., 2019). However, when the stool sample preserved in maltodextrin and trehalose was rapidly processed with oxygen did not affect the bacterial viability, especially for oxygen-sensitive Firmicutes phylum (Burz et al., 2019). Stool preserved in medium (patent no. $\mathrm{N}^{\circ} 1 \mathrm{H} 53316$ CAS $25 \mathrm{FR}$ ) containing antioxidants showed $58.51 \%$ cell viability when exposed to oxygen for 90 minutes (Bellali et al., 2019). The understanding of this notion is vital for the improvement of techniques for maintaining the viability of bacteria.

\section{PROCESSING OF DONOR STOOLS FOR FMT PREPARATION}

\subsection{Mouse Donor Stool Processing}

There is frequently some discrepancy in FMT preparation across institutes and labs. However, the overall process is similar and includes mixing feces with a bacteriostatic fluid, eliminating particulate substance, and transporting feces to the recipient. Depending on the dosage and number of FMT, a large quantity of stool can be used for FMT preparation (Thaiss et al., 2014; Barcena et al., 2019; Stebegg et al., 2019; Sun et al., 2019). On the day of FMT, either fresh feces can be diluted in the sterilized phosphate-buffered saline (PBS) to get an estimated fecal suspension (Sivan et al., 2015; Sun et al., 2019). Frozen aliquot fecal suspension can be defrosted for around 10-15 minutes in a water bath at $37^{\circ} \mathrm{C}$ and appended with L-cysteine amino acid. L-Cysteine is used as a medium, reducing agent to preserve anaerobes. Mixing of feces can also be done with filtered autoclaved water (Ericsson et al., 2017), 200 proof ethanol (Lin et al., 2019) and $\mathrm{NaCl}$ as alternatives for PBS. It is recommended FMT should be executed within 6 hours after defrosting. Besides, it is recommended that the dilution ratio of the feces could be adjusted in FMT preparation (Rasmussen et al., 2019). The feces can be diluted approximately 3 times (Stebegg et al., 2019) to 6 times (Barcena et al., 2019) with PBS. As more than half of the stool bacteria are non-cultivable, it is hard to know the number of live bacteria in the donor samples. Vigorously shaking or homogenization of the feces suspension is endorsed to confirm proper mixing (Ericsson et al., 2017). The fecal suspension should be filtered with a filter or gauze to clear away sizeable particulate matter. Further, centrifugation can be performed to pelleting out undissolved solids matter (Liu et al., 2020). Centrifugation speed varies for FMT preparation such as $500 \times g$ for $5 \mathrm{~min}$, (Stebegg et al., 2019) $800 \times \mathrm{g}$ for $3 \mathrm{~min}$, (Lai et al., 2018) $2000 \times \mathrm{g}$ for $5 \mathrm{~min}$ (Liu et al., 2020) and $5000 \times \mathrm{g}$ for $20 \mathrm{~min}$ at $20^{\circ} \mathrm{C}$. (Zhou et al., 2019) Low-speed centrifugation was probably performed to remove particulate matter, and highspeed centrifugation to concentrate bacteria.

\subsection{Human Donor Stool Processing}

Although trivial differences depend on the specific condition, most organizations prepare the stool centered on a similar protocol. Varieties of stool diluents, such as sterile $\mathrm{NaCl}, \mathrm{PBS}$, and skim milk + BHI media (Gough et al., 2011; Brandt and Aroniadis, 2013; Wrzosek et al., 2018) are used to mix feces. The fecal materials' dilution ratio could be adjusted, considering heterogeneity in the fecal microbes between different individuals or donors (Smits et al., 2013) and advised to be diluted 3-5 times with PBS (Cammarota et al., 2017). Fresh feces should be transported on an icebox to a particular laboratory within 2 hours after excretion (Lee et al., 2016). Feces should be filtered three times through gauze (Mattila et al., 2012), cell strainer, or $0.25 \mathrm{~mm}$ stainless steel mesh to remove the undigested and small solid particles in the fecal suspension (Owens et al., 2013). The fecal suspension could be centrifuged $6000 \times \mathrm{g}$ for $15 \mathrm{~min}$ to remove insolubilized material (Hamilton et al., 2012; Staley et al., 2017).

Notably, all apparatus and solutions used in the fecal suspension preparation should be strictly sterilized. All fecal material preparation processes should be carried out at a room temperature of $20-30^{\circ} \mathrm{C}$, preferably in an anaerobic chamber (Rossen et al., 2015). 


\section{DOSAGE STRATEGY FOR FMT}

The best FMT dose up strategy depends on the disease and the type of bacteria to be studied. Staley and his colleagues quantified the donor's microbial load for FMT preparations using a PetroffHauser counting chamber under a microscope (Staley et al., 2017). However, the attainment of FMT mostly depends on the recipient bacterial richness rather than the composition of the donor's fecal samples. Low microbial load in the recipient can help in improved colonizing of donor microbiota (Sarrabayrouse et al., 2020). The dose-volume and duration of fecal microbiota administration range from a single dose to twice a week for numerous weeks (Hintze et al., 2014; Wrzosek et al., 2018). The scheme using only one dose of FMT was not recommended as there is a cage-dependent shift of the gut microbiota over time, potentially due to the low stability of the transplanted microbiome (Wrzosek et al., 2018). In comparison, FMT twice a week for several weeks can affect the engraftment and trouble the strength of the newly formed microbial ecosystem. FMT twice during the first week allows engraftment of sub-dominant microbes, such as Bifidobacterium (Wrzosek et al., 2018). FMT of the human stool to mice once a week for four weeks may be the best settlement, as it allowed the engraftment of dominant bacteria, such as Faecalibacterium, which was not identified without repeated FMT (Wrzosek et al., 2018). The suggested maximum volume for the administration of FMT is $2 \%$ of body weight, especially for the mouse. The appropriate amount of fecal infusion is challenging to define. Agreement varies such as $100 \mu \mathrm{l}$ per dose, (Sivan et al., 2015) $200 \mu$ l per dose (Sun et al., 2019) 300 $\mu \mathrm{l}$ per dose (Ericsson et al., 2017) and $400 \mu \mathrm{l}$ per dose (Lin et al., 2019). FMT performed via gastric gavage is advised to infuse feces on three consecutive days, beginning immediately after discontinuation of antibiotics and placement on untreated drinking water (Ericsson et al., 2017) corrected disturbed the gut microbiota (Le Bastard et al., 2018). Overall, it is suggested that repeated gavages once a week for 12 weeks can be a good approach to maintain the human donor microbiota population for 12 weeks (Hintze et al., 2014). The human gut microbiota was reported in recipient mice four weeks post-FMT, irrespective of the FMT approach (Wrzosek et al., 2018). Presently, it is not clear how many FMT dosages are essential to sustain the donor microbiota in the recipient in the long-term or if any association exist between FMT dosages and the donor's sustainability microbiota. Therefore, upcoming work is desired to conclude the optimal dose. It also not fully defined whether a specific microbial community composition affects the efficiency of FMT. Forthcoming studies might also check this parameter to evaluate the efficacy of FMT at numerous time points and dosages.

\section{DELIVERY ROUTES OF FMT}

\subsection{Oral-Gastric Gavage}

There is no general agreement on the best approach for delivering fecal microbiota or on the optimal volume. However, oral gastric gavage is a common and preferred method of defined oral dosing for FMT experiments in mice. Fecal suspension may be administered straight into the stomach of mice via a technique called oral-gastric gavage (Sivan et al., 2015). In this method, a stainless-steel bulb tilted gavage needle or a flexible cannula or tube is attached to a syringe and used to deliver the fecal suspension into the stomach. The suggested needle or vessel dimension should be equivalent to the distance from the mouth to exactly after the last rib of the abdominal. Before oral gastric gavage, any anesthesia is not recommended, as this will surge the threat of aspiration pneumonia in mice (Turner et al., 2011). Simple oral-gastric gavage administration of mouse donor microbiota effectively remodels gut microbiota in mouse recipients (Zhang et al., 2015; Rausch et al., 2016). This technique remains the most extensively used method for FMT. It also allows for a quicker transfer of feces. Obstacles linked with this method include unintentional administration into the trachea, bronchial pneumonia, esophageal injury or trauma, stomach rupture, and weight loss (de Meijer et al., 2010; ArantesRodrigues et al., 2012; Kinder et al., 2014). Stress-induced by this method (Balcombe et al., 2004) can enhance morbidity and mortality in mice.

\subsection{Enema}

Per rectum administration of fecal materials by enema is less common in animals than in humans. FMT by enema may be a practical approach to reduce necrotizing enterocolitis progression. Enema reduces intestinal inflammation and increases intestinal barrier function in mice (Liu et al., 2020). For performing enema, a $4 \%$ chloral hydrate/kg body weight solution should be injected intraperitoneal to induce mild anesthesia. The mice should be positioned into the horizontal situation, followed by placement of a plastic tube of $2 \mathrm{~mm}$ inner diameter. After applying paraffin oil onto the tube surface, the tube inserts into the colon through the anus approximately $4 \mathrm{~cm}$. The fecal suspension solution should be injected slowly (Zhou et al., 2019). FMT administered via oral gavage can be nasty in taste and can also cause gastric irritation. Rectum favors a reproducible absorption course. Rectum has little enzymatic actions as compared to other parts of the gut. Further, it is anatomically relatively easy for rectally administered FMT to spread the distal portion of the colon than the proximal part of the colon. The disadvantage of enema is associated with leakage of the rectum, unpredictable absorption, and risk of injury to the rectum's inner lining that could lead to infection.

\subsection{Cohousing}

One of the most straightforward approaches to evaluating an involved gut microbiome's effect on a documented phenotype is the cohousing of affected and unaffected animals already harboring complex microbial populations. Cohousing works on the hypothesis that the gut microbiome of affected animals will be transferred to cagemates, probably via stochastic contact to gut microbiota-associated microbes in the environment or entire coprophagy (Ivanov et al., 2008). Cohousing can also be achieved using groupings of colonized and GF mice as a means of assessing the ability of microbial communities to colonize the GF mice (Seedorf et al., 2014). As with FMT, GF mice can be cohoused with colonized mice at various ages to determine the 
effects of early life events in the adult host (Hansen et al., 2012). Cohousing offers numerous logistical benefits to other methods comprising negligible cost and expertise. However, it is not recommended when donor and recipient are fed different diets consist either high-fat high-sucrose or crude extract of camu camu (Anhe et al., 2019). Cohousing also cannot be executed for human microbiota transfer to mice (Llopis et al., 2016). It also depends on passive, partial, and selective exchanges of microbes between co-housed mice. As a result, a lack of phenotype transfer between co-housed mice does not necessarily remove the involvement of the gut microbiota to the phenotype. By contrast, the positive transmission of specific microbiota directly through oral gavage or other techniques to recipient mice offers direct and clear evidence of a microbial influence (Bel et al., 2014).

\section{PREPARATION OF RECIPIENT FOR FMT}

\subsection{Age of Recipient}

The age of the recipient determines significant engraftment of donor bacteria (Le Roy et al., 2018). Donor microbiota engrafted better in 3-week old mice compared to 8-week old mice. FMT is more competent if the recipient's microbiota displays lower richness (Ericsson et al., 2017). Gut microbiota has been less diverse at weaning, probably associated with diet transition from mother milk to a solid diet (Schloss et al., 2012). Microbial diversity surges with age (Zhang et al., 2015) and reaches stability around 8-week of age (Laukens et al., 2016). The immune system is not much prone to alteration by the bacterial influx, perhaps post 8 weeks of age, because of improved stability of the immune system and gut microbiome homeostasis (Laukens et al., 2016). Bowel cleansing is reported more effective in weaning mice (3 weeks old) than in adults (8 weeks old) (Le Roy et al., 2018). Further, the antibiotic treatment causes a long-term alteration in the gut microbiome at the weaning than adult stage (Cox et al., 2014). Considering the provided reports, weaning might be a window of opportunity for FMT.

\subsection{Methods of Depleting Recipient Microbiota}

\subsubsection{Antibiotics Administration}

The gut microbiota acts as a barricade against the invasion of external microorganisms. The basis of the antibiotic treatment is to drop the gut microbiome load in the recipient to ease competition for the repopulating gut microbiome from the donor. The success of FMT is more reliant on the recipient's microbial load than the composition of the donor's feces. Low bacterial load in the recipient can help in better colonizing of donor microbiota (Sarrabayrouse et al., 2020). Antibiotics administration decreases the microbial load in the recipient that would favor better engraftment of donor microbiota (Sarrabayrouse et al., 2020). FMT effectiveness in mice could be higher in the antibiotic treated gut than bowel cleansing treated gut and untreated gut (Ji et al., 2017). Antibiotics have a profound effect on the gut microbiota of recipients; therefore, various concoctions of antibiotics, as well as routes of administration, may demonstrate variable efficacy (Johnson et al., 2004). Treatment with broad-spectrum antibiotics is commonly used to deplete the gut microbiome of mice before FMT. Due to variances in the mechanism of action, antibiotics can selectively diminish different microbes. Multiple alternating antibiotic concoctions courses may help allow stable engraftment of the human gut microbiome in recipient mice (Hintze et al., 2014). The specific antibiotic can change the composition of the gut microbiome to recognize bacterial classes related to different phenotypes (Schubert et al., 2015; Zackular et al., 2016). Some antibiotic treatment protocols additionally include antifungals to avoid fungal overgrowth (Grasa et al., 2015; Zakostelska et al., 2016). Investigators have used numerous antibiotic régimes, which differ in the recipe, dosage, and treatment length (Table 1). Often, antibiotics are diluted in drinking water, and mice are allowed to drink during treatment; therefore, actually delivered doses can differ. Water solutions are endorsed to make freshly and change once or twice a week (Smith et al., 2013). Many also supplement sweeteners such as sugar or Kool-aid drink mix to disguise any antibiotics' bitterness (Baldridge et al., 2015; Emal et al., 2017). Still, studies of mice avoided drinking water and becoming dehydrated when provided antibiotics with sweeteners or sugar (Reikvam et al., 2011; Zakostelska et al., 2016). Oral gavage can stop dehydration and permit the delivery of antibiotics. The oral gastric gavage method is occasionally used alone or mixed with delivery in drinking water (Reikvam et al., 2011). Broad-spectrum antibiotics deplete intestinal microbiota. However, leftover antibiotics might persist in recipients and might affect the engraftment of donor bacteria; thus, FMT is often performed one or two days after the last day of antibiotic treatment. Depending upon the starting bacterial diversity, antibiotic concoction, and length of treatment, resistance to antibiotics may confound results in FMT research.

\subsubsection{Polyethylene Glycol Administration}

Bowel cleansing with laxative based methods such as PEG is an alternative approach for removing gut microbiota before implantation of the donor gut microbiome. The PEG increases the volume of fluids via osmotic flow and washes out the luminal bacteria. It also introduces oxygen into the colon, which generally harbors anaerobic bacteria ecosystem and declines the nutrition for them (Strocchi et al., 1990). The higher dose of PEG through oral gastric gavage perhaps permitted a more efficient bowel clean. Recent findings suggested $170 \mathrm{mg}$ of PEG for 4 times at 20 minutes intervals (Wrzosek et al., 2018) and 93 mg of PEG for 5 times at 30 minutes intervals (Le Roy et al., 2018) for clearing the gut and reducing the bacterial load in adult and young mice, respectively. PEG alone can lead to a similar decrease in the quantity of a combination of antibiotics. The PEG method is easy and straightforward to use for diminishing resident bacteria from the gut. The PEG solution causes electrolytes disturbance, dehydration (Yamano et al., 2016; Tropini et al., 2018), and change in the protective mucus lining of the colon, which leads to diarrhea in recipients (Johansson et al., 2014; Jalanka et al., 2015).

In contrast with antibiotics, laxatives temporarily decrease the abundance of gut bacteria ecosystem in humans 
TABLE 1 | Antibiotics regimens for depletion of the gut microbiota in recipient mice.

\begin{tabular}{|c|c|c|c|c|c|c|}
\hline $\begin{array}{l}\text { Antibiotics } \\
\text { administration }\end{array}$ & Antibiotics concoction & Dosage & Duration & Add-ons & $\begin{array}{l}\text { Depletion of gut } \\
\text { microbiota }\end{array}$ & References \\
\hline \multirow[t]{10}{*}{ Drinking water } & $\begin{array}{l}\text { Metronidazole + } \\
\text { Vancomycin }\end{array}$ & $1.0+0.5 \mathrm{~g} / \mathrm{L}$ & 10 weeks & & & $\begin{array}{l}\text { (Atarashi et al., } \\
\text { 2011) }\end{array}$ \\
\hline & Penicillin + Streptomycin & $2000 \mathrm{U} / \mathrm{mL}+2 \mathrm{mg} / \mathrm{mL}$ & 3 days & & & (Zhou et al., 2017) \\
\hline & $\begin{array}{l}\text { Ampicillin + Vancomycin + } \\
\text { Polymixin }\end{array}$ & $1.0+0.5+0.1 \mathrm{~g} / \mathrm{L}$ & 4 weeks & & $\begin{array}{l}\text { Depletion in microbiota } \\
\text { noticed }\end{array}$ & (Kim et al., 2017) \\
\hline & $\begin{array}{l}\text { Neomycin + Vancomycin + } \\
\text { Invanz }\end{array}$ & $1.0+1.0+1.0 \mathrm{mg} / \mathrm{mL}$ & 7 days & & $\begin{array}{l}\text { Significant reduction in } \\
\text { bacterial diversity }\end{array}$ & (Staley et al., 2017) \\
\hline & $\begin{array}{l}\text { Neomycin + Metronidazole } \\
+ \text { Vancomycin }\end{array}$ & $1.0+1.0+0.5 \mathrm{~g} / \mathrm{L}$ & 7 days & & & $\begin{array}{l}\text { (Kinnebrew et al., } \\
\text { 2010) }\end{array}$ \\
\hline & $\begin{array}{l}\text { Streptomycin + Colistin + } \\
\text { Ampicillin }\end{array}$ & $5+1+1 \mathrm{~g} / \mathrm{L}$ & 6 weeks & $\begin{array}{l}2.5 \% \\
\text { sucrose }\end{array}$ & & (Sawa et al., 2011) \\
\hline & $\begin{array}{l}\text { Ampicillin + Kanamycin + } \\
\text { Metronidazole + } \\
\text { Vancomycin }\end{array}$ & $1.0+1.0+1.0+0.5 \mathrm{~g} / \mathrm{L}$ & 3 weeks & & A $10^{3}$ drop in gut bacteria & $\begin{array}{l}\text { (Gury-BenAri et al., } \\
\text { 2016) }\end{array}$ \\
\hline & $\begin{array}{l}\text { Ampicillin + Neomycin + } \\
\text { Metronidazole + }\end{array}$ & $1.0+1.0+1.0+0.5 \mathrm{~g} / \mathrm{mL}$ & 7 days & & $\begin{array}{l}\text { A } 10^{5} \text { - fold drop in fecal } \\
\text { microbes }\end{array}$ & $\begin{array}{l}\text { (Ochoa-Reparaz } \\
\text { et al., 2009) }\end{array}$ \\
\hline & Vancomycin & & 2 weeks & $\begin{array}{l}\text { Grape Kool } \\
\text { aid (20 g/L) }\end{array}$ & $\begin{array}{l}\text { A } \sim 10^{5} \text { - to } 10^{6} \text {-fold } \\
\text { reduction in fecal bacteria }\end{array}$ & $\begin{array}{l}\text { (Josefsdottir et al., } \\
\text { 2017) }\end{array}$ \\
\hline & & $1.0+1.0+1.0+0.35 \mathrm{~g} / \mathrm{L}$ & 2 weeks & $\begin{array}{l}\text { Grape Kool- } \\
\text { Aid (25 g/L) }\end{array}$ & & $\begin{array}{l}\text { (Emal et al., 2017; } \\
\text { Thackray et al., } \\
\text { 2018; Burrello et al., } \\
\text { 2018) }\end{array}$ \\
\hline \multirow[t]{6}{*}{$\begin{array}{l}\text { Oral-gastric } \\
\text { gavage }\end{array}$} & $\begin{array}{l}\text { Ampicillin + Neomycin + } \\
\text { Metronidazole + } \\
\text { Vancomycin }\end{array}$ & $\begin{array}{l}1.0+1.0+1.0+0.5 \mathrm{~g} / \mathrm{L} \\
(200 \mu \mathrm{L} / \text { day })\end{array}$ & 7 days & & $\begin{array}{l}\text { A } 10^{6} \text { - fold drop in fecal } \\
\text { bacteria }\end{array}$ & $\begin{array}{l}\text { (Ochoa-Reparaz } \\
\text { et al., 2009) }\end{array}$ \\
\hline & $\begin{array}{l}\text { Ampicillin + Neomycin }+ \\
\text { Metronidazole }+ \\
\text { Vancomycin + Gentamicin }\end{array}$ & $\begin{array}{l}1.0+1.0+1.0+0.5+1.0 \mathrm{~g} / \mathrm{mL} \\
(200 \mu \mathrm{l} / \text { day })\end{array}$ & 3 days & & $\begin{array}{l}\text { Nearly complete reduction } \\
\text { of gut bacteria }\end{array}$ & (Kelly et al., 2015) \\
\hline & $\begin{array}{l}\text { Bacitracin }+ \text { Neomycin }+ \\
\text { Streptomycin }\end{array}$ & 200 mg/antibiotics/kg body weight & 3 days & & $\begin{array}{l}\text { 13-fold decrement in SCFA } \\
\text { levels }\end{array}$ & $\begin{array}{l}\text { (Fernandez- } \\
\text { Santoscoy et al., } \\
\text { 2015) }\end{array}$ \\
\hline & $\begin{array}{l}\text { Ampicillin + Metronidazole + } \\
\text { Vancomycin }\end{array}$ & $2.5+2.5+1.25 \mathrm{mg} / \mathrm{L}(200 \mu \mathrm{l} /$ day $)$ & 3 days & & & (Sun et al., 2019) \\
\hline & Neomycin + Bacitracin & 20mg/antibiotics/mouse & 7 days & $\begin{array}{l}\text { Pimaricin } \\
\text { (5 } \mathrm{\mu g} / \text { mouse })\end{array}$ & $\begin{array}{l}1000 \text {-fold reduction in gut } \\
\text { bacteria }\end{array}$ & (Grasa et al., 2015) \\
\hline & $\begin{array}{l}\text { Ampicillin by drinking water } \\
\text { Neomycin + Metronidazole } \\
+ \text { Vancomycin by oral- } \\
\text { gastric gavage }\end{array}$ & $\begin{array}{l}1.0 \mathrm{~g} / \mathrm{L} 100+100+50 \mathrm{mg} / \mathrm{kg} / \\
\text { mouse } / 12 \mathrm{~h}\end{array}$ & 17 days & $\begin{array}{l}\text { Amphotericin } \\
\text { B (1 g/L) }\end{array}$ & & (Hintze et al., 2014) \\
\hline \multirow[t]{2}{*}{$\begin{array}{l}\text { Drinking water+ } \\
\text { Oral-gastric } \\
\text { gavage }\end{array}$} & $\begin{array}{l}\text { Ampicillin }+ \text { Neomycin }+ \\
\text { Metronidazole }+ \\
\text { Vancomycin }\end{array}$ & $\begin{array}{l}10 \mathrm{mg} / \text { daily/antibiotics/oral-gastric } \\
\text { gavage } 1.0+1.0+1.0+0.5 \mathrm{~g} / \mathrm{L} \text { in } \\
\text { drinking water }\end{array}$ & $\begin{array}{l}5 \text { days } 7- \\
10 \text { days }\end{array}$ & & $\begin{array}{l}\text { A million-fold reduction in } \\
\text { gut bacteria }\end{array}$ & (Kuss et al., 2011) \\
\hline & & $\begin{array}{l}0.35-4+2.15+0.45+0.35 \mathrm{mg} / \mathrm{mL} \\
+8500 \mathrm{U} / \mathrm{mL}(100 \mu \text { l daily by oral- }\end{array}$ & & & $\begin{array}{l}\text { Significant reduction in gut } \\
\text { bacterial }\end{array}$ & (Stefka et al., 2014) \\
\hline
\end{tabular}


TABLE 1 | Continued

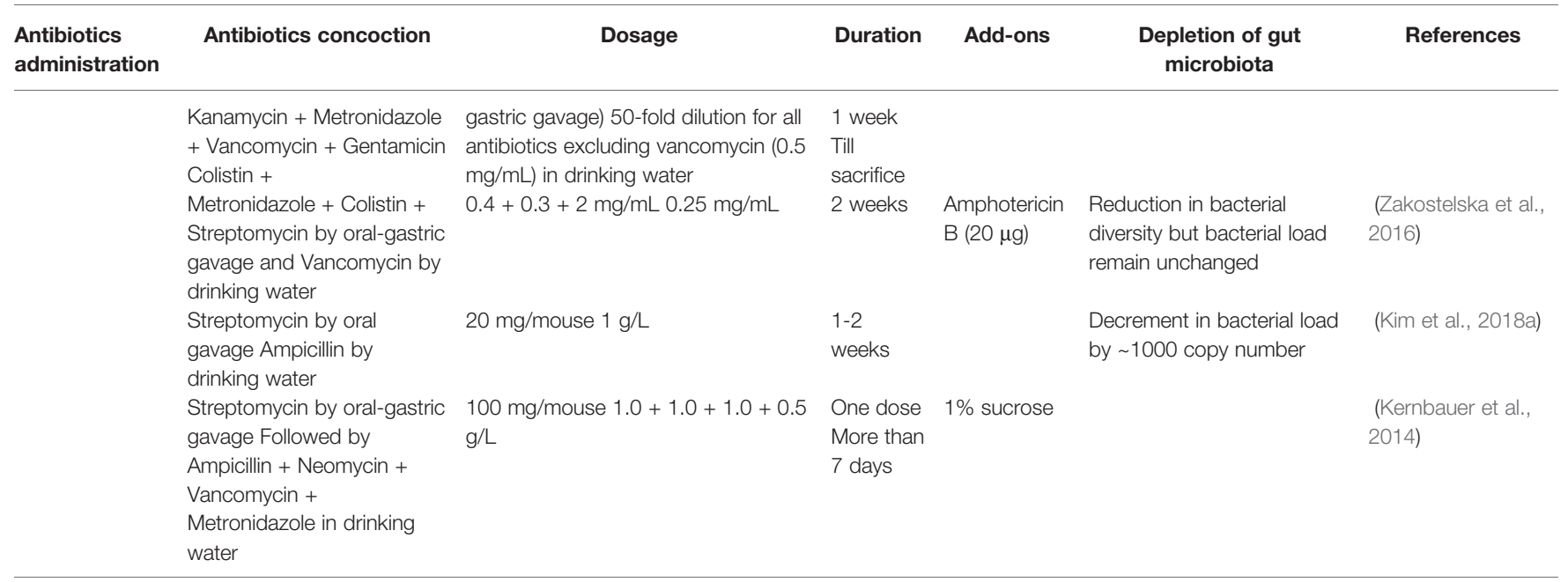

(Jalanka et al., 2015) and mice (Ji et al., 2017). Bowel cleansing also maintained indigenous microbiota post-treatment compared to antibiotics (Ji et al., 2017).

\subsubsection{Germ-Free Mice}

Germ-free (GF) animals provide a valuable investigational tool for inspecting connections between a host and its GM. GF animals free from bacteria, viruses, fungi, protozoa, and parasites, throughout their lifespan (Al-Asmakh and Zadjali, 2015). The physiological conditions in the GF gut are different from wild type and specific pathogen-free mice gut. Precisely, increased mucin, $\mathrm{pH}$, urea and $\mathrm{O}_{2}$, and low or lack of short-chain fatty acids (SCFAs) (Al-Asmakh and Zadjali, 2015) are among the many typical variances that can have a substantial impact on gut microbiota engraftment (Gillilland et al., 2012; Tomas et al., 2013). Along with stabilization in colonization, GF mice's innate and adaptive immune system requires 30 days to be functional (El Aidy et al., 2013). GF mice must often be examined for contamination using a combination of bacterial culture, microscopy, serology, gross morphology, and sequencing-based detection techniques (Fontaine et al., 2015; Nicklas et al., 2015).

Additionally, the preservation of GF mice in isolators are quite expensive and limit wide application. The cost and management of isolators may make it impracticable or challenging to conduct behavioral testing or pathological study using GF mice. Overall, these parameters should be considered for planning experimental designs and interpreting results related to microbiota composition analysis and phenotype transmission (Le Roy et al., 2018).

\section{ENGRAFTMENT OF GUT MICROBIOTA POST-FMT}

The engraftment of the gut microbiome can be examined by alpha and beta diversity. The extent of donor engraftment can be tracked using a Bayesian Source Tracker algorithm, an OTUbased approach (Knights et al., 2011; Staley et al., 2016; Staley et al., 2017). Several studies reported success in the donor microbiota colonization post-FMT with a varied range of engraftment (Table 2). Transfer of human gut microbiota into GF mice by FMT results in the successful transfer of $85-88 \%$ of genera after seven days (Turnbaugh et al., 2009; Staley et al., 2017). Approximately 52-58\% of donor mice microbiota successfully transferred in recipient mice post one week of the last dose of FMT and engraftment was maintained for the next three weeks (Ericsson et al., 2017). Further, 57-68\% human donor microbial population could be attained post weekly gavage for 12 weeks. Staley and his research group reported engraftment ranging from $63.4 \%$ to $87.9 \%$ to specific pathogen-free mice at day three post single dose of antibiotics cocktail. ${ }^{76}$ While engraftment fell marginally post day 3 , high levels of donor similarity were retained for the three weeks. Multiple doses of antibiotics cocktail increase the percentage of engraftment compared to a single dose of antibiotics, but it did not increase significantly. The microbiota in control mice without antibiotics cocktail treatment displayed higher similarity ( $89.4 \%$ to $95.0 \%$ ) to their microbiota post-FMT rather than donor microbiota, suggesting antibiotic treatment is required for an effective FMT (Turnbaugh et al., 2009; Staley et al., 2017).

Interestingly, not all the bacteria in the donor stool have equal colonization capacity. Bacteriodetes phylum was more successful in colonization compared to Firmicutes phylum (Hintze et al., 2014). It is also important to note that at least some microbiota interactions with the host immune system can only be mediated by host-specific microbiota. The colonization of mice with human microbiota does not fully restore microbiota-associated colonization resistance against some pathogens (Chung et al., 2012; Le Roy et al., 2018).

\section{IMPACT OF RECIPIENT IMMUNE STATUS ON FMT}

The gut microbiota alterations post-FMT employ an intense effect on the immune status of the recipient. It can be a crucial 
TABLE 2 | FMT dosage details and success rates of FMT.

\begin{tabular}{|c|c|c|c|c|c|c|c|c|c|}
\hline Host & Recipient & $\begin{array}{l}\text { Age of } \\
\text { recipient }\end{array}$ & Time of FMT & Fecal content & $\begin{array}{c}\text { FMT } \\
\text { method }\end{array}$ & FMT dose & $\begin{array}{l}\text { Duration } \\
\text { of FMT }\end{array}$ & $\begin{array}{l}\text { FMT } \\
\text { success } \\
\text { rate }\end{array}$ & References \\
\hline Human & Mice & 7 weeks & $\begin{array}{l}12 \mathrm{hr} \text { after } \\
\text { microbiota } \\
\text { depletion }\end{array}$ & $\begin{array}{l}\text { Frozen fecal material } \\
\text { reconstituted in sterile } \\
\text { saline }\end{array}$ & $\begin{array}{l}\text { Oral- } \\
\text { gastric } \\
\text { gavage }\end{array}$ & & $\begin{array}{l}\text { Weekly for } \\
12 \text { weeks }\end{array}$ & $\begin{array}{l}57-68 \% \\
\text { after } 12 \\
\text { weeks }\end{array}$ & $\begin{array}{l}\text { (Hintze } \\
\text { et al., 2014) }\end{array}$ \\
\hline Human & $\begin{array}{l}\text { Mice/GF } \\
\text { mice }\end{array}$ & $\begin{array}{l}6-8 \\
\text { weeks }\end{array}$ & $\begin{array}{l}\text { Immediately after } \\
\text { microbiota } \\
\text { depletion }\end{array}$ & $\begin{array}{l}\text { Frozen fecal material } \\
\text { amended with 10\% } \\
\text { glycerol }\end{array}$ & $\begin{array}{l}\text { Oral- } \\
\text { gastric } \\
\text { gavage }\end{array}$ & $100 \mu \mathrm{L}$ & $\begin{array}{l}\text { Single } \\
\text { dose }\end{array}$ & $\begin{array}{l}\sim 60 \% \text { after } \\
3 \text { days }\end{array}$ & $\begin{array}{l}\text { (Staley } \\
\text { et al., 2017) }\end{array}$ \\
\hline Human & GF Mice & $\begin{array}{l}5-7 \\
\text { weeks }\end{array}$ & $\begin{array}{l}\text { No microbiota } \\
\text { depletion before } \\
\text { FMT }\end{array}$ & $\begin{array}{l}\text { Freshly voided fecal } \\
\text { sample diluted in reduced } \\
\text { PBS }\end{array}$ & $\begin{array}{l}\text { Oral- } \\
\text { gastric } \\
\text { gavage }\end{array}$ & $200 \mu \mathrm{L}$ & $\begin{array}{l}\text { Single } \\
\text { dose }\end{array}$ & $\begin{array}{l}88 \% \text { after } 7 \\
\text { days }\end{array}$ & $\begin{array}{l}\text { (Turnbaugh } \\
\text { et al., 2009) }\end{array}$ \\
\hline $\begin{array}{l}\text { Humanized } \\
\text { GF Mice }\end{array}$ & GF Mice & $\begin{array}{l}10 \\
\text { weeks }\end{array}$ & $\begin{array}{l}\text { No microbiota } \\
\text { depletion before } \\
\text { FMT }\end{array}$ & $\begin{array}{l}\text { Frozen fecal diluted in } \\
\text { reduced PBS }\end{array}$ & $\begin{array}{l}\text { Oral- } \\
\text { gastric } \\
\text { gavage }\end{array}$ & $200 \mu \mathrm{L}$ & $\begin{array}{l}\text { Single } \\
\text { dose }\end{array}$ & $\begin{array}{l}85 \% \text { after } 7 \\
\text { days }\end{array}$ & $\begin{array}{l}\text { (Turnbaugh } \\
\text { et al., 2009) }\end{array}$ \\
\hline $\begin{array}{l}\text { C57BL/6N } \\
\text { Mice }\end{array}$ & $\begin{array}{l}\text { C57BL/ } \\
6 N \text { Mice }\end{array}$ & $\begin{array}{l}\text { 6-10 } \\
\text { weeks }\end{array}$ & $\begin{array}{l}24 \mathrm{hr} \text { after } \\
\text { microbiota } \\
\text { depletion }\end{array}$ & $\begin{array}{l}\text { Fresh fecal pellets } \\
\text { suspended in reduced } \\
\text { PBS }\end{array}$ & $\begin{array}{l}\text { Oral- } \\
\text { gastric } \\
\text { gavage }\end{array}$ & $\begin{array}{l}100 \mu \mathrm{L} \text { (Twice a day for } \\
\text { first } 2 \text { weeks and later } \\
\text { once a week) }\end{array}$ & $\begin{array}{l}\text { Till natural } \\
\text { death or } \\
\text { sacrifice }\end{array}$ & $\begin{array}{l}2 \text { weeks } \\
\text { after first } \\
\text { dose of FMT }\end{array}$ & $\begin{array}{l}\text { (Barcena } \\
\text { et al., 2019) }\end{array}$ \\
\hline Mice & Mice & 7 weeks & $\begin{array}{l}48 \mathrm{hr} \text { after } \\
\text { microbiota } \\
\text { depletion }\end{array}$ & $\begin{array}{l}\text { Feces were suspended in } \\
\text { PBS }\end{array}$ & $\begin{array}{l}\text { Oral- } \\
\text { gastric } \\
\text { gavage }\end{array}$ & $200 \mu\llcorner/$ day & 3 days & & $\begin{array}{l}\text { (Le Bastard } \\
\text { et al., 2018) }\end{array}$ \\
\hline $\begin{array}{l}\text { C57BL/6J } \\
\text { or WSB/EiJ } \\
\text { Mice }\end{array}$ & $\begin{array}{l}\text { C57BL/6J } \\
\text { Mice }\end{array}$ & 4 weeks & $\begin{array}{l}\text { Immediately after } \\
\text { microbiota } \\
\text { depletion }\end{array}$ & $\begin{array}{l}\text { Dried fecal material was } \\
\text { suspended in PBS }\end{array}$ & $\begin{array}{l}\text { Oral- } \\
\text { gastric } \\
\text { Gavage }\end{array}$ & $100 \mu \mathrm{L}$ & $\begin{array}{l}\text { Single } \\
\text { dose }\end{array}$ & & $\begin{array}{l}\text { (Nazmul } \\
\text { Huda et al., } \\
\text { 2020) }\end{array}$ \\
\hline $\begin{array}{l}\text { Balb/c } \\
\text { Mice }\end{array}$ & $\begin{array}{l}\text { C57BL/ } \\
\text { 6Mice }\end{array}$ & $\begin{array}{l}3-5 \\
\text { months }\end{array}$ & $\begin{array}{l}\text { 5hr after microbiota } \\
\text { depletion }\end{array}$ & $\begin{array}{l}\text { Fecal samples were } \\
\text { stored in } 10 \% \text { glycerol at } \\
-80^{\circ} \mathrm{C} \text { until use }\end{array}$ & $\begin{array}{l}\text { Oral- } \\
\text { gastric } \\
\text { Gavage }\end{array}$ & $200 \mu \mathrm{L}$ & $\begin{array}{l}\text { Single } \\
\text { dose }\end{array}$ & $19.21 \%$ & $\begin{array}{l}\text { (Freitag } \\
\text { et al., 2019) }\end{array}$ \\
\hline $\begin{array}{l}\text { C57BL/6 } \\
\text { Mice }\end{array}$ & $\begin{array}{l}\text { C57BL/6 } \\
\text { Mice }\end{array}$ & 6 weeks & $\begin{array}{l}\text { Immediately after } \\
\text { microbiota } \\
\text { depletion treatment }\end{array}$ & $\begin{array}{l}\text { Fresh and frozen fecal } \\
\text { samples diluted in sterile } \\
\text { water prior FMT }\end{array}$ & $\begin{array}{l}\text { Oral- } \\
\text { gastric } \\
\text { gavage }\end{array}$ & $300 \mu \mathrm{L} /$ day & 3 days & $58-90 \%$ & $\begin{array}{l}\text { (Ericsson } \\
\text { et al., 2017) }\end{array}$ \\
\hline
\end{tabular}

parameter in the success of FMT-based therapeutics. A study has shown that mice without $\mathrm{CD}^{+}{ }^{+} \mathrm{Foxp}^{+}{ }^{+}$-regulatory cells were unable to resolve CDI post-FMT and exacerbated inflammation with failure of engraftment of donor microbiota (Littmann et al., 2021). However, removing B-cells, CD8-positive T cells, Th17, and Th1 cells did not affect the success of FMT in CDI mice (Littmann et al., 2021). Success of FMT might involve other immune cells such as innate lymphoid cells and mucosalassociated invariant $\mathrm{T}$ cells that regulate host gut immune homeostasis (Fan et al., 2019; Ioannidis et al., 2020). Hostderived inflammatory byproducts such as reactive oxygen and nitrogen species promote the growth of inflammation-tolerant pathogens (Winter et al., 2013). Further, inflammation-induced metabolites ethanolamine, nitric acid, formic acid, and lactic acid also simultaneously support the growth of inflammationtolerant bacteria (Thiennimitr et al., 2011; Spees et al., 2013; Hughes and Winter, 2016; Gillis et al., 2018) and may prevent engraftment of microbiota (Littmann et al., 2021). Transplantation studies demonstrated that outcome of grafts is driven by the compatibility of major histocompatibility complex [MHC, called human leukocyte antigen (HLA) in human] within and between species (Trivedi et al., 2007; Ayala Garcia et al., 2012). Interestingly, MHC class II and HLA-DQ2 expression influences gut microbiota composition in mice (Kubinak et al., 2015; Khan et al., 2019) and human (Olivares et al., 2015) respectively. Therefore, it is probable that incompatibilities with human microbiota transplantation into mice are also influenced by MHC when introducing foreign microbes.
Though this is not the only contributing factor, it can be an important consideration in FMT studies. Overall, these reports suggested that the recipient's specific immune status can exploit the effectiveness or success of FMT. A more extensive characterization of host immune status is needed to understand its role in the engraftment of donor microbiota.

\section{FECAL COMPONENTS OTHER THAN BACTERIA FOR FMT}

Most studies on FMT have focused explicitly on the bacteria component of the microbiota. Even though this is a crucial feature, FMT comprises the transfer of more than bacteria. Viruses, fungi, and microbial metabolites are also components of feces and may affect the recipient (Bojanova and Bordenstein, 2016). Ott et al. demonstrated that fecal suspension of the donor was influential in the treatment of recurrent CDI patients. They reported similarity in phage community six weeks post-FMT in recipient compared to donor (Ott et al., 2017). Gavage of phages of a high-fat diet-fed donor helped in reducing small intestinal bacterial overgrowth in high-fat diet-fed recipient mice (Lin et al., 2019). Patients with recurrent CDI displayed fungal dysbiosis. Improvement after FMT was related to a higher abundance of donor-derived Saccharomyces and Aspergillus in recipients (Zuo et al., 2018). Microbial metabolites such as short-chain fatty acids (SCFAs) have been shown to noticeable 
anti-inflammatory and $\mathrm{T}$ cell-inducing functions in the host (Arpaia et al., 2013; Smith et al., 2013). Further, FMT rich in SCFAs supplemented with butyric acid effectively managed ischemic stroke (Chen et al., 2019). Understanding link between donor non-bacterial components and host-microbiota throughout the intestine is a crucial next footstep in discovering the prospective of FMT based treatments for numerous forms of gut dysbiosis.

\section{CONCLUSIONS}

Despite the many studies using FMT to test the causal link of the microbiome in diseases, a multitude of variables of FMT procedures differ between research labs and institutions, and there is no scientific harmony on the standard methodology. An evidence-based approach and routine assessment of stool and

\section{REFERENCES}

Al-Asmakh, M., and Zadjali, F. (2015). Use of Germ-Free Animal Models in Microbiota-Related Research. J. Microbiol. Biotechnol. 25 (10), 1583-1588. doi: $10.4014 /$ jmb.1501.01039

Anhe, F. F., Nachbar, R. T., Varin, T. V., Trottier, J., Dudonne, S., Le Barz, M., et al. (2019). Treatment With Camu Camu (Myrciaria Dubia) Prevents Obesity by Altering the Gut Microbiota and Increasing Energy Expenditure in Diet-Induced Obese Mice. Gut 68 (3), 453-464. doi: 10.1136/gutjnl-2017315565

Arantes-Rodrigues, R., Henriques, A., Pinto-Leite, R., Faustino-Rocha, A., PinhoOliveira, J., Teixeira-Guedes, C., et al. (2012). The Effects of Repeated Oral Gavage on the Health of Male CD-1 Mice. Lab. Anim. (NY) 41 (5), 129-134. doi: 10.1038/laban0512-129

Arpaia, N., Campbell, C., Fan, X., Dikiy, S., van der Veeken, J., deRoos, P., et al. (2013). Metabolites Produced by Commensal Bacteria Promote Peripheral Regulatory T-Cell Generation. Nature 504 (7480), 451-455. doi: 10.1038/ nature 12726

Atarashi, K., Tanoue, T., Shima, T., Imaoka, A., Kuwahara, T., Momose, Y., et al. (2011). Induction of Colonic Regulatory T Cells by Indigenous Clostridium Species. Science 331 (6015), 337-341. doi: 10.1126/science.1198469

Ayala Garcia, M. A., Gonzalez Yebra, B., Lopez Flores, A. L., and Guani Guerra, E. (2012). The Major Histocompatibility Complex in Transplantation. J. Transplant. 2012, 842141. doi: 10.1155/2012/842141

Bahl, M. I., Bergstrom, A., and Licht, T. R. (2012). Freezing Fecal Samples Prior to DNA Extraction Affects the Firmicutes to Bacteroidetes Ratio Determined by Downstream Quantitative PCR Analysis. FEMS Microbiol. Lett. 329 (2), $193-$ 197. doi: 10.1111/j.1574-6968.2012.02523.x

Bajaj, J. S., Kassam, Z., Fagan, A., Gavis, E. A., Liu, E., Cox, I. J., et al. (2017). Fecal Microbiota Transplant From a Rational Stool Donor Improves Hepatic Encephalopathy: A Randomized Clinical Trial. Hepatol. 66 (6), 1727-1738. doi: 10.1002/hep.29306

Bakken, J. S., Borody, T., Brandt, L. J., Brill, J. V., Demarco, D. C., Franzos, M. A., et al. (2011). Treating Clostridium Difficile Infection With Fecal Microbiota Transplantation. Clin. Gastroenterol. Hepatol. 9 (12), 1044-1049. doi: 10.1016/ j.cgh.2011.08.014

Balcombe, J. P., Barnard, N. D., and Sandusky, C. (2004). Laboratory Routines Cause Animal Stress. Contemp. Top. Lab. Anim. Sci. 43 (6), 42-51.

Baldridge, M. T., Nice, T. J., McCune, B. T., Yokoyama, C. C., Kambal, A., Wheadon, M., et al. (2015). Commensal Microbes and Interferon-Lambda Determine Persistence of Enteric Murine Norovirus Infection. Science 347 (6219), 266-269. doi: 10.1126/science.1258025

Barba, C., Soulage, C. O., Caggiano, G., Glorieux, G., Fouque, D., and Koppe, L. (2020). Effects of Fecal Microbiota Transplantation on Composition in Mice With CKD. Toxins (Basel) 12 (12), 741. doi: 10.3390/toxins12120741
FMT preparation protocol are required to maximize FMT effects and ensure the reproducible outcome.

\section{AUTHOR CONTRIBUTIONS}

YZ and SB conceived the study, SB wrote the manuscript. YZ, $\mathrm{YD}$, and HP assisted in writing the manuscript. All authors contributed to the article and approved the submitted version.

\section{FUNDING}

This work was supported by the NINDS through R01 NS102633-04.

Barcena, C., Valdes-Mas, R., Mayoral, P., Garabaya, C., Durand, S., Rodriguez, F., et al. (2019). Healthspan and Lifespan Extension by Fecal Microbiota Transplantation Into Progeroid Mice. Nat. Med. 25 (8), 1234-1242. doi: 10.1038/s41591-019-0504-5

Béal, C., and Fonseca, F. (2015). "Freezing of Probiotic Bacteria". in Advances in Probiotic Technology. Eds. P. Foerst and C. Santivarangkna (Boca Raton: CRC Press) 179-212. doi: 10.1201/b18807-14

Bel, S., Elkis, Y., Elifantz, H., Koren, O., Ben-Hamo, R., Lerer-Goldshtein, T., et al. (2014). Reprogrammed and Transmissible Intestinal Microbiota Confer Diminished Susceptibility to Induced Colitis in TMF-/- Mice. Proc. Natl. Acad. Sci. U. S. A. 111 (13), 4964-4969. doi: 10.1073/pnas.1319114111

Bellali, S., Lagier, J. C., Raoult, D., and Bou Khalil, J. (2019). Among Live and Dead Bacteria, the Optimization of Sample Collection and Processing Remains Essential in Recovering Gut Microbiota Components. Front. Microbiol. 10, 1606. doi: 10.3389/fmicb.2019.01606

Ben-Amor, K., Heilig, H., Smidt, H., Vaughan, E. E., Abee, T., and de Vos, W. M. (2005). Genetic Diversity of Viable, Injured, and Dead Fecal Bacteria Assessed by Fluorescence-Activated Cell Sorting and 16S rRNA Gene Analysis. Appl. Environ. Microbiol. 71 (8), 4679-4689. doi: 10.1128/AEM.71.8.4679-4689.2005

Berer, K., Gerdes, L. A., Cekanaviciute, E., Jia, X., Xiao, L., Xia, Z., et al. (2017). Gut Microbiota From Multiple Sclerosis Patients Enables Spontaneous Autoimmune Encephalomyelitis in Mice. Proc. Natl. Acad. Sci. U. S. A. 114 (40), 10719-10724. doi: 10.1073/pnas.1711233114

Bojanova, D. P., and Bordenstein, S. R. (2016). Fecal Transplants: What Is Being Transferred? PLoS Biol. 14 (7), e1002503. doi: 10.1371/journal.pbio.1002503

Brandt, L. J., and Aroniadis, O. C. (2013). An Overview of Fecal Microbiota Transplantation: Techniques, Indications, and Outcomes. Gastrointest. Endosc. 78 (2), 240-249. doi: 10.1016/j.gie.2013.03.1329

Brusa, T., Canzi, E., Pacini, N., Zanchi, R., and Ferrari, A. (1989). Oxygen Tolerance of Anaerobic Bacteria Isolated From Human Feces. Curr. Microbiol. 19 (1), 39-43. doi: 10.1007/BF01568901

Burrello, C., Garavaglia, F., Cribiu, F. M., Ercoli, G., Bosari, S., Caprioli, F., et al. (2018). Short-Term Oral Antibiotics Treatment Promotes Inflammatory Activation of Colonic Invariant Natural Killer T and Conventional CD4(+) T Cells. Front. Med. (Lausanne) 5, 21. doi: 10.3389/fmed.2018.00021

Burz, S. D., Abraham, A. L., Fonseca, F., David, O., Chapron, A., Beguet-Crespel, F., et al. (2019). A Guide for Ex Vivo Handling and Storage of Stool Samples Intended for Fecal Microbiota Transplantation. Sci. Rep. 9 (1), 8897. doi: 10.1038/s41598-019-45173-4

Cammarota, G., Ianiro, G., and Gasbarrini, A. (2014). Fecal Microbiota Transplantation for the Treatment of Clostridium Difficile Infection: A Systematic Review. J. Clin. Gastroenterol. 48 (8), 693-702. doi: 10.1097/MCG.0000000000000046

Cammarota, G., Ianiro, G., Tilg, H., Rajilic-Stojanovic, M., Kump, P., Satokari, R., et al. (2017). European Consensus Conference on Faecal Microbiota Transplantation in Clinical Practice. Gut 66 (4), 569-580. doi: 10.1136/ gutjnl-2016-313017 
Carlson, P. E. Jr. (2020). Regulatory Considerations for Fecal Microbiota Transplantation Products. Cell Host Microbe 27 (2), 173-175. doi: 10.1016/ j.chom.2020.01.018

Carroll, I. M., Ringel-Kulka, T., Siddle, J. P., Klaenhammer, T. R., and Ringel, Y. (2012). Characterization of the Fecal Microbiota Using High-Throughput Sequencing Reveals a Stable Microbial Community During Storage. PLoS One 7 (10), e46953. doi: 10.1371/journal.pone.0046953

Cenit, M. C., Sanz, Y., and Codoner-Franch, P. (2017). Influence of Gut Microbiota on Neuropsychiatric Disorders. World J. Gastroenterol. 23 (30), 5486-5498. doi: 10.3748/wjg.v23.i30.5486

Chang, C., and Lin, H. (2016). Dysbiosis in Gastrointestinal Disorders. Best Pract. Res. Clin. Gastroenterol. 30 (1), 3-15. doi: 10.1016/j.bpg.2016.02.001

Chen, R., Xu, Y., Wu, P., Zhou, H., Lasanajak, Y., Fang, Y., et al. (2019). Transplantation of Fecal Microbiota Rich in Short Chain Fatty Acids and Butyric Acid Treat Cerebral Ischemic Stroke by Regulating Gut Microbiota. Pharmacol. Res. 148, 104403. doi: 10.1016/j.phrs.2019.104403

Choo, J. M., Leong, L. E., and Rogers, G. B. (2015). Sample Storage Conditions Significantly Influence Faecal Microbiome Profiles. Sci. Rep. 5, 16350. doi: $10.1038 /$ srep 16350

Chung, H., Pamp, S. J., Hill, J. A., Surana, N. K., Edelman, S. M., Troy, E. B., et al. (2012). Gut Immune Maturation Depends on Colonization With a HostSpecific Microbiota. Cell 149 (7), 1578-1593. doi: 10.1016/j.cell.2012.04.037

Cox, L. M., Yamanishi, S., Sohn, J., Alekseyenko, A. V., Leung, J. M., Cho, I., et al. (2014). Altering the Intestinal Microbiota During a Critical Developmental Window has Lasting Metabolic Consequences. Cell 158 (4), 705-721. doi: $10.1016 /$ j.cell.2014.05.052

Dabke, K., Hendrick, G., and Devkota, S. (2019). The Gut Microbiome and Metabolic Syndrome. J. Clin. Invest. 129 (10), 4050-4057. doi: 10.1172/JCI129194

de Meijer, V. E., Le, H. D., Meisel, J. A., and Puder, M. (2010). Repetitive Orogastric Gavage Affects the Phenotype of Diet-Induced Obese Mice. Physiol. Behav. 100 (4), 387-393. doi: 10.1016/j.physbeh.2010.04.001

De Palma, G., Lynch, M. D., Lu, J., Dang, V. T., Deng, Y., Jury, J., et al. (2017). Transplantation of Fecal Microbiota From Patients With Irritable Bowel Syndrome Alters Gut Function and Behavior in Recipient Mice. Sci. Transl. Med. 9 (379), eaaf6397. doi: 10.1126/scitranslmed.aaf6397

Diaz Heijtz, R., Wang, S., Anuar, F., Qian, Y., Bjorkholm, B., Samuelsson, A., et al. (2011). Normal Gut Microbiota Modulates Brain Development and Behavior. Proc. Natl. Acad. Sci. U. S. A. 108 (7), 3047-3052. doi: 10.1073/pnas.1010529108

Durand, A., Audemard-Verger, A., Guichard, V., Mattiuz, R., Delpoux, A., Hamon, P., et al. (2018). Profiling the Lymphoid-Resident T Cell Pool Reveals Modulation by Age and Microbiota. Nat. Commun. 9 (1), 68. doi: 10.1038/s41467-017-02458-4

El Aidy, S., Hooiveld, G., Tremaroli, V., Backhed, F., and Kleerebezem, M. (2013). The Gut Microbiota and Mucosal Homeostasis: Colonized at Birth or at Adulthood, Does It Matter? Gut Microbes 4 (2), 118-124. doi: 10.4161/gmic.23362

Elinav, E., Strowig, T., Kau, A. L., Henao-Mejia, J., Thaiss, C. A., Booth, C. J., et al. (2011). NLRP6 Inflammasome Regulates Colonic Microbial Ecology and Risk for Colitis. Cell 145 (5), 745-757. doi: 10.1016/j.cell.2011.04.022

Emal, D., Rampanelli, E., Stroo, I., Butter, L. M., Teske, G. J., Claessen, N., et al. (2017). Depletion of Gut Microbiota Protects Against Renal IschemiaReperfusion Injury. J. Am. Soc. Nephrol. 28 (5), 1450-1461. doi: 10.1681/ ASN.2016030255

Ericsson, A. C., Gagliardi, J., Bouhan, D., Spollen, W. G., Givan, S. A., and Franklin, C. L. (2018). The Influence of Caging, Bedding, and Diet on the Composition of the Microbiota in Different Regions of the Mouse Gut. Sci. Rep. 8 (1), 4065. doi: 10.1038/s41598-018-21986-7

Ericsson, A. C., Personett, A. R., Turner, G., Dorfmeyer, R. A., and Franklin, C. L. (2017). Variable Colonization After Reciprocal Fecal Microbiota Transfer Between Mice With Low and High Richness Microbiota. Front. Microbiol. 8, 196. doi: 10.3389/fmicb.2017.00196

Evrensel, A., and Ceylan, M. E. (2016). Fecal Microbiota Transplantation and Its Usage in Neuropsychiatric Disorders. Clin. Psychopharmacol. Neurosci. 14 (3), 231-237. doi: 10.9758/cpn.2016.14.3.231

Fadda, H. M. (2020). The Route to Palatable Fecal Microbiota Transplantation. AAPS Pharm. Sci. Tech. 21 (3), 114. doi: 10.1208/s12249-020-1637-z

Fan, H., Wang, A., Wang, Y., Sun, Y., Han, J., Chen, W., et al. (2019). Innate Lymphoid Cells: Regulators of Gut Barrier Function and Immune Homeostasis. J. Immunol. Res. 2019, 2525984. doi: 10.1155/2019/2525984
Felice, V. D., and O'Mahony, S. M. (2017). The Microbiome and Disorders of the Central Nervous System. Pharmacol. Biochem. Behav. 160, 1-13. doi: 10.1016/ j.pbb.2017.06.016

Fernandez-Santoscoy, M., Wenzel, U. A., Yrlid, U., Cardell, S., Backhed, F., and Wick, M. J. (2015). The Gut Microbiota Reduces Colonization of the Mesenteric Lymph Nodes and IL-12-Independent IFN-Gamma Production During Salmonella Infection. Front. Cell Infect. Microbiol. 5, 93. doi: 10.3389/ fcimb.2015.00093

Ferrere, G., Wrzosek, L., Cailleux, F., Turpin, W., Puchois, V., Spatz, M., et al. (2017). Fecal Microbiota Manipulation Prevents Dysbiosis and AlcoholInduced Liver Injury in Mice. J. Hepatol. 66 (4), 806-815. doi: 10.1016/ j.jhep.2016.11.008

Finegold, S. M. (1995). Anaerobic Infections in Humans: An Overview. Anaerobe 1 (1), 3-9. doi: 10.1016/s1075-9964(95)80340-8

Fontaine, C. A., Skorupski, A. M., Vowles, C. J., Anderson, N. E., Poe, S. A., and Eaton, K. A. (2015). How Free of Germs Is Germ-Free? Detection of Bacterial Contamination in a Germ Free Mouse Unit. Gut Microbes 6 (4), 225-233. doi: 10.1080/19490976.2015.1054596

Food and Drug Administration. (2020). Safety Alert Regarding Use of Fecal Microbiota for Transplantation and Risk of Serious Adverse Events Likely Due to Transmission of Pathogenic Organisms (Rockville, MD: Food and Drug Administration).

Freitag, T. L., Hartikainen, A., Jouhten, H., Sahl, C., Meri, S., Anttila, V. J., et al. (2019). Minor Effect of Antibiotic Pre-Treatment on the Engraftment of Donor Microbiota in Fecal Transplantation in Mice. Front. Microbiol. 10, 2685. doi: $10.3389 /$ fmicb. 2019.02685

Ganal, S. C., Sanos, S. L., Kallfass, C., Oberle, K., Johner, C., Kirschning, C., et al. (2012). Priming of Natural Killer Cells by Nonmucosal Mononuclear Phagocytes Requires Instructive Signals From Commensal Microbiota. Immunity 37 (1), 171-186. doi: 10.1016/j.immuni.2012.05.020

Gillilland, M. G. 3rd, Erb-Downward, J. R., Bassis, C. M., Shen, M. C., Toews, G. B., Young, V. B., et al. (2012). Ecological Succession of Bacterial Communities During Conventionalization of Germ-Free Mice. Appl. Environ. Microbiol. 78 (7), 2359-2366. doi: 10.1128/AEM.05239-11

Gillis, C. C., Hughes, E. R., Spiga, L., Winter, M. G., Zhu, W., Furtado de Carvalho, T., et al. (2018). Dysbiosis-Associated Change in Host Metabolism Generates Lactate to Support Salmonella Growth. Cell Host Microbe 23 (1), 54-64.e6. doi: 10.1016/j.chom.2017.11.006

Gough, E., Shaikh, H., and Manges, A. R. (2011). Systematic Review of Intestinal Microbiota Transplantation (Fecal Bacteriotherapy) for Recurrent Clostridium Difficile Infection. Clin. Infect. Dis. 53 (10), 994-1002. doi: 10.1093/cid/cir632

Grasa, L., Abecia, L., Forcen, R., Castro, M., de Jalon, J. A., Latorre, E., et al. (2015). Antibiotic-Induced Depletion of Murine Microbiota Induces Mild Inflammation and Changes in Toll-Like Receptor Patterns and Intestinal Motility. Microb. Ecol. 70 (3), 835-848. doi: 10.1007/s00248-015-0613-8

Gury-BenAri, M., Thaiss, C. A., Serafini, N., Winter, D. R., Giladi, A., LaraAstiaso, D., et al. (2016). The Spectrum and Regulatory Landscape of Intestinal Innate Lymphoid Cells Are Shaped by the Microbiome. Cell 166 (5), 1231 1246.e13. doi: 10.1016/j.cell.2016.07.043

Hamilton, M. J., Weingarden, A. R., Sadowsky, M. J., and Khoruts, A. (2012). Standardized Frozen Preparation for Transplantation of Fecal Microbiota for Recurrent Clostridium Difficile Infection. Am. J. Gastroenterol. 107 (5), 761767. doi: 10.1038/ajg.2011.482

Hansen, C. H., Nielsen, D. S., Kverka, M., Zakostelska, Z., Klimesova, K., Hudcovic, T., et al. (2012). Patterns of Early Gut Colonization Shape Future Immune Responses of the Host. PLoS One 7 (3), e34043. doi: 10.1371/journal.pone.0034043

Hintze, K. J., Cox, J. E., Rompato, G., Benninghoff, A. D., Ward, R. E., Broadbent, J., et al. (2014). Broad Scope Method for Creating Humanized Animal Models for Animal Health and Disease Research Through Antibiotic Treatment and Human Fecal Transfer. Gut Microbes 5 (2), 183-191. doi: 10.4161/gmic.28403

Hughes, E. R., and Winter, S. E. (2016). Enterococcus Faecalis: E. Coli's Siderophore-Inducing Sidekick. Cell Host Microbe 20 (4), 411-412. doi: 10.1016/j.chom.2016.09.018

Human Microbiome Project (2012a). A Framework for Human Microbiome Research. Nature 486 (7402), 215-221. doi: 10.1038/nature11209

Human Microbiome Project (2012b). Structure, Function and Diversity of the Healthy Human Microbiome. Nature 486 (7402), 207-214. doi: 10.1038/ nature 11234 
Ioannidis, M., Cerundolo, V., and Salio, M. (2020). The Immune Modulating Properties of Mucosal-Associated Invariant T Cells. Front. Immunol. 11, 1556. doi: 10.3389 /fimmu.2020.01556

Ivanov, I. I., Frutos Rde, L., Manel, N., Yoshinaga, K., Rifkin, D. B., Sartor, R. B., et al. (2008). Specific Microbiota Direct the Differentiation of IL-17-Producing T-Helper Cells in the Mucosa of the Small Intestine. Cell Host Microbe 4 (4), 337-349. doi: 10.1016/j.chom.2008.09.009

Jalanka, J., Salonen, A., Salojarvi, J., Ritari, J., Immonen, O., Marciani, L., et al. (2015). Effects of Bowel Cleansing on the Intestinal Microbiota. Gut 64 (10), 1562-1568. doi: 10.1136/gutjnl-2014-307240

Ji, S. K., Yan, H., Jiang, T., Guo, C. Y., Liu, J. J., Dong, S. Z., et al. (2017). Preparing the Gut With Antibiotics Enhances Gut Microbiota Reprogramming Efficiency by Promoting Xenomicrobiota Colonization. Front. Microbiol. 8, 1208. doi: $10.3389 /$ fmicb.2017.01208

Johansson, M. E., Gustafsson, J. K., Holmen-Larsson, J., Jabbar, K. S., Xia, L., Xu, H., et al. (2014). Bacteria Penetrate the Normally Impenetrable Inner Colon Mucus Layer in Both Murine Colitis Models and Patients With Ulcerative Colitis. Gut 63 (2), 281-291. doi: 10.1136/gutjnl-2012-303207

Johnson, S. A., Nicolson, S. W., and Jackson, S. (2004). The Effect of Different Oral Antibiotics on the Gastrointestinal Microflora of a Wild Rodent (Aethomys Namaquensis). Comp. Biochem. Physiol. A Mol. Integr. Physiol. 138 (4), 475483. doi: 10.1016/j.cbpb.2004.06.010

Josefsdottir, K. S., Baldridge, M. T., Kadmon, C. S., and King, K. Y. (2017). Antibiotics Impair Murine Hematopoiesis by Depleting the Intestinal Microbiota. Blood 129 (6), 729-739. doi: 10.1182/blood-2016-03-708594

Kang, D. W., Adams, J. B., Gregory, A. C., Borody, T., Chittick, L., Fasano, A., et al. (2017). Microbiota Transfer Therapy Alters Gut Ecosystem and Improves Gastrointestinal and Autism Symptoms: An Open-Label Study. Microbiome 5 (1), 10. doi: 10.1186/s40168-016-0225-7

Kelly, C. J., Zheng, L., Campbell, E. L., Saeedi, B., Scholz, C. C., Bayless, A. J., et al. (2015). Crosstalk Between Microbiota-Derived Short-Chain Fatty Acids and Intestinal Epithelial HIF Augments Tissue Barrier Function. Cell Host Microbe 17 (5), 662-671. doi: 10.1016/j.chom.2015.03.005

Kernbauer, E., Ding, Y., and Cadwell, K. (2014). An Enteric Virus Can Replace the Beneficial Function of Commensal Bacteria. Nature 516 (7529), 94-98. doi: 10.1038/nature 13960

Khan, A. A., Yurkovetskiy, L., O’Grady, K., Pickard, J. M., de Pooter, R., Antonopoulos, D. A., et al. (2019). Polymorphic Immune Mechanisms Regulate Commensal Repertoire. Cell Rep. 29 (3), 541-550.e4. doi: 10.1016/ j.celrep.2019.09.010

Khosravi, A., Yanez, A., Price, J. G., Chow, A., Merad, M., Goodridge, H. S., et al. (2014). Gut Microbiota Promote Hematopoiesis to Control Bacterial Infection. Cell Host Microbe 15 (3), 374-381. doi: 10.1016/j.chom.2014.02.006

Kim, S. H., Cho, B. H., Kiyono, H., and Jang, Y. S. (2017). Microbiota-Derived Butyrate Suppresses Group 3 Innate Lymphoid Cells in Terminal Ileal Peyer's Patches. Sci. Rep. 7 (1), 3980. doi: 10.1038/s41598-017-02729-6

Kim, S. M., DeFazio, J. R., Hyoju, S. K., Sangani, K., Keskey, R., Krezalek, M. A., et al. (2020). Fecal Microbiota Transplant Rescues Mice From Human Pathogen Mediated Sepsis by Restoring Systemic Immunity. Nat. Commun. 11 (1), 2354 . doi: 10.1038/s41467-020-15545-w

Kim, M., Galan, C., Hill, A. A., Wu, W. J., Fehlner-Peach, H., Song, H. W., et al. (2018a). Critical Role for the Microbiota in CX3CR1(+) Intestinal Mononuclear Phagocyte Regulation of Intestinal $\mathrm{T}$ Cell Responses. Immunity 49 (1), 151-163.e5. doi: 10.1016/j.immuni.2018.05.009

Kim, T. T., Parajuli, N., Sung, M. M., Bairwa, S. C., Levasseur, J., Soltys, C. M., et al. (2018b). Fecal Transplant From Resveratrol-Fed Donors Improves Glycaemia and Cardiovascular Features of the Metabolic Syndrome in Mice. Am. J. Physiol. Endocrinol. Metab. 315 (4), E511-E519. doi: 10.1152/ajpendo.00471.2017

Kinder, J. M., Then, J. E., Hansel, P. M., Molinero, L. L., and Bruns, H. A. (2014). Long-Term Repeated Daily Use of Intragastric Gavage Hinders Induction of Oral Tolerance to Ovalbumin in Mice. Comp. Med. 64 (5), 369-376.

Kinnebrew, M. A., Ubeda, C., Zenewicz, L. A., Smith, N., Flavell, R. A., and Pamer, E. G. (2010). Bacterial Flagellin Stimulates Toll-Like Receptor 5-Dependent Defense Against Vancomycin-Resistant Enterococcus Infection. J. Infect. Dis. 201 (4), 534-543. doi: 10.1086/650203

Knights, D., Kuczynski, J., Charlson, E. S., Zaneveld, J., Mozer, M. C., Collman, R. G., et al. (2011). Bayesian Community-Wide Culture-Independent Microbial Source Tracking. Nat. Methods 8 (9), 761-763. doi: 10.1038/nmeth.1650
Kubinak, J. L., Stephens, W. Z., Soto, R., Petersen, C., Chiaro, T., Gogokhia, L., et al. (2015). MHC Variation Sculpts Individualized Microbial Communities That Control Susceptibility to Enteric Infection. Nat. Commun. 6, 8642. doi: $10.1038 /$ ncomms 9642

Kuss, S. K., Best, G. T., Etheredge, C. A., Pruijssers, A. J., Frierson, J. M., Hooper, L. V., et al. (2011). Intestinal Microbiota Promote Enteric Virus Replication and Systemic Pathogenesis. Science 334 (6053), 249-252. doi: 10.1126/ science. 1211057

Lai, Z. L., Tseng, C. H., Ho, H. J., Cheung, C. K. Y., Lin, J. Y., Chen, Y. J., et al. (2018). Fecal Microbiota Transplantation Confers Beneficial Metabolic Effects of Diet and Exercise on Diet-Induced Obese Mice. Sci. Rep. 8 (1), 15625. doi: 10.1038/s41598-018-33893-y

Lauber, C. L., Zhou, N., Gordon, J. I., Knight, R., and Fierer, N. (2010). Effect of Storage Conditions on the Assessment of Bacterial Community Structure in Soil and Human-Associated Samples. FEMS Microbiol. Lett. 307 (1), 80-86. doi: 10.1111/j.1574-6968.2010.01965.x

Laukens, D., Brinkman, B. M., Raes, J., De Vos, M., and Vandenabeele, P. (2016). Heterogeneity of the Gut Microbiome in Mice: Guidelines for Optimizing Experimental Design. FEMS Microbiol. Rev. 40 (1), 117-132. doi: 10.1093/ femsre/fuv036

Lawley, T. D., Clare, S., Walker, A. W., Stares, M. D., Connor, T. R., Raisen, C., et al. (2012). Targeted Restoration of the Intestinal Microbiota With a Simple, Defined Bacteriotherapy Resolves Relapsing Clostridium Difficile Disease in Mice. PLoS Pathog. 8 (10), e1002995. doi: 10.1371/journal.ppat.1002995

Le Bastard, Q., Ward, T., Sidiropoulos, D., Hillmann, B. M., Chun, C. L., Sadowsky, M. J., et al. (2018). Fecal Microbiota Transplantation Reverses Antibiotic and Chemotherapy-Induced Gut Dysbiosis in Mice. Sci. Rep. 8 (1), 6219. doi: $10.1038 / \mathrm{s} 41598-018-24342-x$

Lee, J., d'Aigle, J., Atadja, L., Quaicoe, V., Honarpisheh, P., Ganesh, B. P., et al. (2020). Gut Microbiota-Derived Short-Chain Fatty Acids Promote Post-Stroke Recovery in Aged Mice. Circ. Res 127 (4), 453-465. doi: 10.1161/ CIRCRESAHA.119.316448

Lee, C. H., Steiner, T., Petrof, E. O., Smieja, M., Roscoe, D., Nematallah, A., et al. (2016). Frozen vs Fresh Fecal Microbiota Transplantation and Clinical Resolution of Diarrhea in Patients With Recurrent Clostridium Difficile Infection: A Randomized Clinical Trial. JAMA 315 (2), 142-149. doi: 10.1001/jama.2015.18098

Le Roy, T., Debedat, J., Marquet, F., Da-Cunha, C., Ichou, F., Guerre-Millo, M., et al. (2018). Comparative Evaluation of Microbiota Engraftment Following Fecal Microbiota Transfer in Mice Models: Age, Kinetic and Microbial Status Matter. Front. Microbiol. 9, 3289. doi: 10.3389/fmicb.2018.03289

Liang, X., Bushman, F. D., and FitzGerald, G. A. (2015). Rhythmicity of the Intestinal Microbiota Is Regulated by Gender and the Host Circadian Clock. Proc. Natl. Acad. Sci. U. S. A. 112 (33), 10479-10484. doi: 10.1073/ pnas. 1501305112

Li, F., Hao, X., Chen, Y., Bai, L., Gao, X., Lian, Z., et al. (2017). The Microbiota Maintain Homeostasis of Liver-Resident gammadeltaT-17 Cells in a Lipid Antigen/CD1d-Dependent Manner. Nat. Commun. 7, 13839. doi: 10.1038/ ncomms 13839

Lin, D. M., Koskella, B., Ritz, N. L., Lin, D., Carroll-Portillo, A., and Lin, H. C. (2019). Transplanting Fecal Virus-Like Particles Reduces High-Fat DietInduced Small Intestinal Bacterial Overgrowth in Mice. Front. Cell Infect. Microbiol. 9, 348. doi: 10.3389/fcimb.2019.00348

Littmann, E. R., Lee, J. J., Denny, J. E., Alam, Z., Maslanka, J. R., Zarin, I., et al. (2021). Host Immunity Modulates the Efficacy of Microbiota Transplantation for Treatment of Clostridioides Difficile Infection. Nat. Commun. 12 (1), 755. doi: 10.1038/s41467-020-20793-x

Liu, J., Miyake, H., Zhu, H., Li, B., Alganabi, M., Lee, C., et al. (2020). Fecal Microbiota Transplantation by Enema Reduces Intestinal Injury in Experimental Necrotizing Enterocolitis. J. Pediatr. Surg. 55 (6), 1094-1098. doi: 10.1016/j.jpedsurg.2020.02.035

Llopis, M., Cassard, A. M., Wrzosek, L., Boschat, L., Bruneau, A., Ferrere, G., et al. (2016). Intestinal Microbiota Contributes to Individual Susceptibility to Alcoholic Liver Disease. Gut 65 (5), 830-839. doi: 10.1136/gutjnl-2015-310585

Mattila, E., Uusitalo-Seppala, R., Wuorela, M., Lehtola, L., Nurmi, H., Ristikankare, M., et al. (2012). Fecal Transplantation, Through Colonoscopy, Is Effective Therapy for Recurrent Clostridium Difficile Infection. Gastroenterology 142 (3), 490-496. doi: 10.1053/j.gastro.2011.11.037 
Nazmul Huda, M., Winnike, J. H., Crowell, J. M., O'Connor, A., and Bennett, B. J. (2020). Microbial Modulation of Host Body Composition and Plasma Metabolic Profile. Sci. Rep. 10 (1), 6545. doi: 10.1038/s41598-020-63214-1

Nicholson, J. K., Holmes, E., Kinross, J., Burcelin, R., Gibson, G., Jia, W., et al. (2012). Host-Gut Microbiota Metabolic Interactions. Science 336 (6086), 12621267. doi: $10.1126 /$ science. 1223813

Nicklas, W., Keubler, L., and Bleich, A. (2015). Maintaining and Monitoring the Defined Microbiota Status of Gnotobiotic Rodents. ILAR J. 56 (2), 241-249. doi: $10.1093 /$ ilar/ilv029

Ochoa-Reparaz, J., Mielcarz, D. W., Ditrio, L. E., Burroughs, A. R., Foureau, D. M., Haque-Begum, S., et al. (2009). Role of Gut Commensal Microflora in the Development of Experimental Autoimmune Encephalomyelitis. J. Immunol. 183 (10), 6041-6050. doi: 10.4049/jimmunol.0900747

Olivares, M., Neef, A., Castillejo, G., Palma, G. D., Varea, V., Capilla, A., et al. (2015). The HLA-DQ2 Genotype Selects for Early Intestinal Microbiota Composition in Infants at High Risk of Developing Coeliac Disease. Gut 64 (3), 406-417. doi: 10.1136/gutjnl-2014-306931

Olszak, T., An, D., Zeissig, S., Vera, M. P., Richter, J., Franke, A., et al. (2012). Microbial Exposure During Early Life has Persistent Effects on Natural Killer T Cell Function. Science 336 (6080), 489-493. doi: 10.1126/science.1219328

Ott, S. J., Waetzig, G. H., Rehman, A., Moltzau-Anderson, J., Bharti, R., Grasis, J. A., et al. (2017). Efficacy of Sterile Fecal Filtrate Transfer for Treating Patients With Clostridium Difficile Infection. Gastroenterology 152 (4), 2799-2811.e7. doi: 10.1053/j.gastro.2016.11.010

Owens, C., Broussard, E., and Surawicz, C. (2013). Fecal Microbiota Transplantation and Donor Standardization. Trends Microbiol. 21 (9), 443445. doi: 10.1016/j.tim.2013.07.003

Papanicolas, L. E., Choo, J. M., Wang, Y., Leong, L. E. X., Costello, S. P., Gordon, D. L., et al. (2019). Bacterial Viability in Faecal Transplants: Which Bacteria Survive? EBioMedicine 41, 509-516. doi: 10.1016/j.ebiom.2019.02.023

Rasmussen, T. S., de Vries, L., Kot, W., Hansen, L. H., Castro-Mejia, J. L., Vogensen, F. K., et al. (2019). Mouse Vendor Influence on the Bacterial and Viral Gut Composition Exceeds the Effect of Diet. Viruses 11 (5), 435. doi: $10.3390 / \mathrm{v} 11050435$

Rausch, P., Basic, M., Batra, A., Bischoff, S. C., Blaut, M., Clavel, T., et al. (2016). Analysis of Factors Contributing to Variation in the C57BL/6J Fecal Microbiota Across German Animal Facilities. Int. J. Med. Microbiol. 306 (5), 343-355. doi: 10.1016/j.ijmm.2016.03.004

Reikvam, D. H., Erofeev, A., Sandvik, A., Grcic, V., Jahnsen, F. L., Gaustad, P., et al. (2011). Depletion of Murine Intestinal Microbiota: Effects on Gut Mucosa and Epithelial Gene Expression. PLoS One 6 (3), e17996. doi: 10.1371/ journal.pone.0017996

Ridaura, V. K., Faith, J. J., Rey, F. E., Cheng, J., Duncan, A. E., Kau, A. L., et al. (2013). Gut Microbiota From Twins Discordant for Obesity Modulate Metabolism in Mice. Science 341 (6150), 1241214. doi: 10.1126/science.1241214

Roka, R., Rosztoczy, A., Leveque, M., Izbeki, F., Nagy, F., Molnar, T., et al. (2007). A Pilot Study of Fecal Serine-Protease Activity: A Pathophysiologic Factor in Diarrhea-Predominant Irritable Bowel Syndrome. Clin. Gastroenterol. Hepatol. 5 (5), 550-555. doi: 10.1016/j.cgh.2006.12.004

Rossen, N. G., Fuentes, S., van der Spek, M. J., Tijssen, J. G., Hartman, J. H., Duflou, A., et al. (2015). Findings From a Randomized Controlled Trial of Fecal Transplantation for Patients With Ulcerative Colitis. Gastroenterology 149 (1), 110-118.e114. doi: 10.1053/j.gastro.2015.03.045

Sarrabayrouse, G., Landolfi, S., Pozuelo, M., Willamil, J., Varela, E., Clark, A., et al. (2020). Mucosal Microbial Load in Crohn's Disease: A Potential Predictor of Response to Faecal Microbiota Transplantation. EBioMedicine 51, 102611. doi: $10.1016 /$ j.ebiom.2019.102611

Sawa, S., Lochner, M., Satoh-Takayama, N., Dulauroy, S., Berard, M., Kleinschek, M., et al. (2011). RORgammat+ Innate Lymphoid Cells Regulate Intestinal Homeostasis by Integrating Negative Signals From the Symbiotic Microbiota. Nat. Immunol. 12 (4), 320-326. doi: 10.1038/ni.2002

Schloss, P. D., Schubert, A. M., Zackular, J. P., Iverson, K. D., Young, V. B., and Petrosino, J. F. (2012). Stabilization of the Murine Gut Microbiome Following Weaning. Gut Microbes 3 (4), 383-393. doi: 10.4161/gmic.21008

Schubert, A. M., Sinani, H., and Schloss, P. D. (2015). Antibiotic-Induced Alterations of the Murine Gut Microbiota and Subsequent Effects on Colonization Resistance Against Clostridium Difficile. mBio 6 (4), e00974. doi: $10.1128 / \mathrm{mBio} .00974-15$
Seedorf, H., Griffin, N. W., Ridaura, V. K., Reyes, A., Cheng, J., Rey, F. E., et al. (2014). Bacteria From Diverse Habitats Colonize and Compete in the Mouse Gut. Cell 159 (2), 253-266. doi: 10.1016/j.cell.2014.09.008

Sergeant, M. J., Constantinidou, C., Cogan, T., Penn, C. W., and Pallen, M. J. (2012). High-Throughput Sequencing of 16S rRNA Gene Amplicons: Effects of Extraction Procedure, Primer Length and Annealing Temperature. PLoS One 7 (5), e38094. doi: 10.1371/journal.pone.0038094

Shaw, A. G., Sim, K., Powell, E., Cornwell, E., Cramer, T., McClure, Z. E., et al. (2016). Latitude in Sample Handling and Storage for Infant Faecal Microbiota Studies: The Elephant in the Room? Microbiome 4 (1), 40. doi: 10.1186/s40168016-0186-x

Shi, N., Li, N., Duan, X., and Niu, H. (2017). Interaction Between the Gut Microbiome and Mucosal Immune System. Mil. Med. Res. 4, 14. doi: 10.1186/s40779-017-0122-9

Sivan, A., Corrales, L., Hubert, N., Williams, J. B., Aquino-Michaels, K., Earley, Z. M., et al. (2015). Commensal Bifidobacterium Promotes Antitumor Immunity and Facilitates Anti-PD-L1 Efficacy. Science 350 (6264), 1084-1089. doi: $10.1126 /$ science.aac4255

Smith, P. M., Howitt, M. R., Panikov, N., Michaud, M., Gallini, C. A., Bohlooly, Y. M., et al. (2013). The Microbial Metabolites, Short-Chain Fatty Acids, Regulate Colonic Treg Cell Homeostasis. Science 341 (6145), 569-573. doi: 10.1126/ science. 1241165

Smits, L. P., Bouter, K. E., de Vos, W. M., Borody, T. J., and Nieuwdorp, M. (2013). Therapeutic Potential of Fecal Microbiota Transplantation. Gastroenterology 145 (5), 946-953. doi: 10.1053/j.gastro.2013.08.058

Spees, A. M., Wangdi, T., Lopez, C. A., Kingsbury, D. D., Xavier, M. N., Winter, S. E., et al. (2013). Streptomycin-Induced Inflammation Enhances Escherichia Coli Gut Colonization Through Nitrate Respiration. mBio 4 (4), e00430-13. doi: $10.1128 / \mathrm{mBio} .00430-13$

Staley, C., Kaiser, T., Beura, L. K., Hamilton, M. J., Weingarden, A. R., Bobr, A., et al. (2017). Stable Engraftment of Human Microbiota Into Mice With a Single Oral Gavage Following Antibiotic Conditioning. Microbiome 5 (1), 87. doi: 10.1186/s40168-017-0306-2

Staley, C., Kelly, C. R., Brandt, L. J., Khoruts, A., and Sadowsky, M. J. (2016). Complete Microbiota Engraftment Is Not Essential for Recovery From Recurrent Clostridium Difficile Infection Following Fecal Microbiota Transplantation. mBio 7 (6), e01965-16. doi: 10.1128/mBio.01965-16

Stebegg, M., Silva-Cayetano, A., Innocentin, S., Jenkins, T. P., Cantacessi, C. Gilbert, C., et al. (2019). Heterochronic Faecal Transplantation Boosts Gut Germinal Centres in Aged Mice. Nat. Commun. 10 (1), 2443. doi: 10.1038/ s41467-019-10430-7

Stefka, A. T., Feehley, T., Tripathi, P., Qiu, J., McCoy, K., Mazmanian, S. K., et al. (2014). Commensal Bacteria Protect Against Food Allergen Sensitization. Proc. Natl. Acad. Sci. U. S. A. 111 (36), 13145-13150. doi: 10.1073/pnas.1412008111

Strocchi, A., Bond, J. H., Ellis, C., and Levitt, M. D. (1990). Colonic Concentrations of Hydrogen and Methane Following Colonoscopic Preparation With an Oral Lavage Solution. Gastrointest. Endosc. 36 (6), 580-582. doi: 10.1016/s00165107(90)71168-6

Sun, J., Xu, J., Ling, Y., Wang, F., Gong, T., Yang, C., et al. (2019). Fecal Microbiota Transplantation Alleviated Alzheimer's Disease-Like Pathogenesis in APP/PS1 Transgenic Mice. Transl. Psychiatry 9 (1), 189. doi: 10.1038/s41398-019-0525-3

Sun, M. F., Zhu, Y. L., Zhou, Z. L., Jia, X. B., Xu, Y. D., Yang, Q., et al. (2018). Neuroprotective Effects of Fecal Microbiota Transplantation on MPTPInduced Parkinson's Disease Mice: Gut Microbiota, Glial Reaction and TLR4/TNF-Alpha Signaling Pathway. Brain Behav. Immun. 70, 48-60. doi: 10.1016/j.bbi.2018.02.005

Takahashi, M., Ishikawa, D., Sasaki, T., Lu, Y. J., Kuwahara-Arai, K., Kamei, M., et al. (2019). Faecal Freezing Preservation Period Influences Colonization Ability for Faecal Microbiota Transplantation. J. Appl. Microbiol. 126 (3), 973984. doi: $10.1111 /$ jam. 14167

Tana, C., Umesaki, Y., Imaoka, A., Handa, T., Kanazawa, M., and Fukudo, S. (2010). Altered Profiles of Intestinal Microbiota and Organic Acids May Be the Origin of Symptoms in Irritable Bowel Syndrome. Neurogastroenterol. Motil. 22 (5), 512-519, e114-e115. doi: 10.1111/j.1365-2982.2009.01427.x

Tedjo, D. I., Jonkers, D. M., Savelkoul, P. H., Masclee, A. A., van Best, N., Pierik, M. J., et al. (2015). The Effect of Sampling and Storage on the Fecal Microbiota Composition in Healthy and Diseased Subjects. PLoS One 10 (5), e0126685. doi: 10.1371 /journal.pone. 0126685 
Thackray, L. B., Handley, S. A., Gorman, M. J., Poddar, S., Bagadia, P., Briseno, C. G., et al. (2018). Oral Antibiotic Treatment of Mice Exacerbates the Disease Severity of Multiple Flavivirus Infections. Cell Rep. 22 (13), 3440-3453. doi: 10.1016/j.celrep.2018.03.001. e3446.

Thaiss, C. A., Zeevi, D., Levy, M., Zilberman-Schapira, G., Suez, J., Tengeler, A. C., et al. (2014). Transkingdom Control of Microbiota Diurnal Oscillations Promotes Metabolic Homeostasis. Cell 159 (3), 514-529. doi: 10.1016/ j.cell.2014.09.048

Thiennimitr, P., Winter, S. E., Winter, M. G., Xavier, M. N., Tolstikov, V., Huseby, D. L., et al. (2011). Intestinal Inflammation Allows Salmonella to Use Ethanolamine to Compete With the Microbiota. Proc. Natl. Acad. Sci. U. S. A. 108 (42), 17480-17485. doi: 10.1073/pnas.1107857108

Thomas, V., Clark, J., and Dore, J. (2015). Fecal Microbiota Analysis: An Overview of Sample Collection Methods and Sequencing Strategies. Future Microbiol. 10 (9), 1485-1504. doi: 10.2217/fmb.15.87

Tomas, J., Wrzosek, L., Bouznad, N., Bouet, S., Mayeur, C., Noordine, M. L., et al. (2013). Primocolonization Is Associated With Colonic Epithelial Maturation During Conventionalization. FASEB J. 27 (2), 645-655. doi: 10.1096/fj.12-216861

Trivedi, V. B., Dave, A. P., Dave, J. M., and Patel, B. C. (2007). Human Leukocyte Antigen and Its Role in Transplantation Biology. Transplant. Proc. 39 (3), 688693. doi: 10.1016/j.transproceed.2007.01.066

Tropini, C., Moss, E. L., Merrill, B. D., Ng, K. M., Higginbottom, S. K., Casavant, E. P., et al. (2018). Transient Osmotic Perturbation Causes Long-Term Alteration to the Gut Microbiota. Cell 173 (7), 1742-1754.e1717. doi: 10.1016/j.cell.2018.05.008

Turnbaugh, P. J., Ridaura, V. K., Faith, J. J., Rey, F. E., Knight, R., and Gordon, J. I. (2009). The Effect of Diet on the Human Gut Microbiome: A Metagenomic Analysis in Humanized Gnotobiotic Mice. Sci. Transl. Med. 1 (6), 6ra14. doi: 10.1126/scitranslmed.3000322

Turner, P. V., Brabb, T., Pekow, C., and Vasbinder, M. A. (2011). Administration of Substances to Laboratory Animals: Routes of Administration and Factors to Consider. J. Am. Assoc. Lab. Anim. Sci. 50 (5), 600-613.

Wang, H., Cui, B., Li, Q., Ding, X., Li, P., Zhang, T., et al. (2018a). The Safety of Fecal Microbiota Transplantation for Crohn's Disease: Findings From A LongTerm Study. Adv. Ther. 35 (11), 1935-1944. doi: 10.1007/s12325-018-0800-3

Wang, Z., Hua, W., Li, C., Chang, H., Liu, R., Ni, Y., et al. (2019). Protective Role of Fecal Microbiota Transplantation on Colitis and Colitis-Associated Colon Cancer in Mice Is Associated With Treg Cells. Front. Microbiol. 10, 2498. doi: $10.3389 /$ fmicb. 2019.02498

Wang, S., Huang, M., You, X., Zhao, J., Chen, L., Wang, L., et al. (2018b). Gut Microbiota Mediates the Anti-Obesity Effect of Calorie Restriction in Mice. Sci. Rep. 8 (1), 1-14. doi: 10.1038/s41598-018-31353-1

Wei, Y. L., Chen, Y. Q., Gong, H., Li, N., Wu, K. Q., Hu, W., et al. (2018). Fecal Microbiota Transplantation Ameliorates Experimentally Induced Colitis in Mice by Upregulating AhR. Front. Microbiol. 9, 1921. doi: 10.3389/ fmicb.2018.01921

Winter, S. E., Winter, M. G., Xavier, M. N., Thiennimitr, P., Poon, V., Keestra, A. M., et al. (2013). Host-Derived Nitrate Boosts Growth of E. Coli in the Inflamed Gut. Science 339 (6120), 708-711. doi: 10.1126/science.1232467

Wrzosek, L., Ciocan, D., Borentain, P., Spatz, M., Puchois, V., Hugot, C., et al. (2018). Transplantation of Human Microbiota Into Conventional Mice Durably Reshapes the Gut Microbiota. Sci. Rep. 8 (1), 6854. doi: 10.1038/ s41598-018-25300-3

Wu, Y. Y., Hsu, C. M., Chen, P. H., Fung, C. P., and Chen, L. W. (2014). Toll-Like Receptor Stimulation Induces Nondefensin Protein Expression and Reverses Antibiotic-Induced Gut Defense Impairment. Infect. Immun. 82 (5), 19942005. doi: 10.1128/IAI.01578-14
Xu, H., Liu, M., Cao, J., Li, X., Fan, D., Xia, Y., et al. (2019). The Dynamic Interplay Between the Gut Microbiota and Autoimmune Diseases. J. Immunol. Res. 2019, 7546047. doi: 10.1155/2019/7546047

Yamano, H. O., Matsushita, H. O., Yoshikawa, K., Takagi, R., Harada, E., Tanaka, Y., et al. (2016). Randomised Clinical Study Comparing the Effectiveness and Physiological Effects of Hypertonic and Isotonic Polyethylene Glycol Solutions for Bowel Cleansing. BMJ Open Gastroenterol. 3 (1), e000101. doi: 10.1136/ bmjgast-2016-000101

Yang, C., Fang, X., Zhan, G., Huang, N., Li, S., Bi, J., et al. (2019). Key Role of Gut Microbiota in Anhedonia-Like Phenotype in Rodents With Neuropathic Pain. Transl. Psychiatry 9 (1), 57. doi: 10.1038/s41398-019-0379-8

Yan, J., Herzog, J. W., Tsang, K., Brennan, C. A., Bower, M. A., Garrett, W. S., et al. (2016). Gut Microbiota Induce IGF-1 and Promote Bone Formation and Growth. Proc. Natl. Acad. Sci. U. S. A. 113 (47), E7554-E7563. doi: 10.1073/ pnas. 1607235113

Zackular, J. P., Baxter, N. T., Chen, G. Y., and Schloss, P. D. (2016). Manipulation of the Gut Microbiota Reveals Role in Colon Tumorigenesis. mSphere 1 (1), e00001-15. doi: 10.1128/mSphere.00001-15

Zakostelska, Z., Malkova, J., Klimesova, K., Rossmann, P., Hornova, M., Novosadova, I., et al. (2016). Intestinal Microbiota Promotes Psoriasis-Like Skin Inflammation by Enhancing Th17 Response. PLoS One 11 (7), e0159539. doi: 10.1371/journal.pone.0159539

Zarrinpar, A., Chaix, A., Yooseph, S., and Panda, S. (2014). Diet and Feeding Pattern Affect the Diurnal Dynamics of the Gut Microbiome. Cell Metab. 20 (6), 1006-1017. doi: 10.1016/j.cmet.2014.11.008

Zhang, H., Sparks, J. B., Karyala, S. V., Settlage, R., and Luo, X. M. (2015). Host Adaptive Immunity Alters Gut Microbiota. ISME J. 9 (3), 770-781. doi: 10.1038/ismej.2014.165

Zhou, D., Pan, Q., Shen, F., Cao, H. X., Ding, W. J., Chen, Y. W., et al. (2017). Total Fecal Microbiota Transplantation Alleviates High-Fat Diet-Induced Steatohepatitis in Mice via Beneficial Regulation of Gut Microbiota. Sci. Rep. 7 (1), 1529. doi: 10.1038/s41598-017-01751-y

Zhou, J., Zhou, Z., Ji, P., Ma, M., Guo, J., and Jiang, S. (2019). Effect of Fecal Microbiota Transplantation on Experimental Colitis in Mice. Exp. Ther. Med. 17 (4), 2581-2586. doi: 10.3892/etm.2019.7263

Zuo, T., Wong, S. H., Cheung, C. P., Lam, K., Lui, R., Cheung, K., et al. (2018). Gut Fungal Dysbiosis Correlates With Reduced Efficacy of Fecal Microbiota Transplantation in Clostridium Difficile Infection. Nat. Commun. 9 (1), 3663. doi: 10.1038/s41467-018-06103-6

Conflict of Interest: The authors declare that the research was conducted in the absence of any commercial or financial relationships that could be construed as a potential conflict of interest.

Publisher's Note: All claims expressed in this article are solely those of the authors and do not necessarily represent those of their affiliated organizations, or those of the publisher, the editors and the reviewers. Any product that may be evaluated in this article, or claim that may be made by its manufacturer, is not guaranteed or endorsed by the publisher.

Copyright (c) 2021 Bokoliya, Dorsett, Panier and Zhou. This is an open-access article distributed under the terms of the Creative Commons Attribution License (CC BY). The use, distribution or reproduction in other forums is permitted, provided the original author(s) and the copyright owner(s) are credited and that the original publication in this journal is cited, in accordance with accepted academic practice. No use, distribution or reproduction is permitted which does not comply with these terms. 